\title{
Atmospheric nitrogen deposition to the northwestern Pacific: seasonal variation and source attribution
}

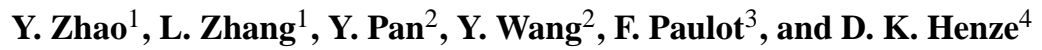 \\ ${ }^{1}$ Laboratory for Climate and Ocean-Atmosphere Sciences, Department of Atmospheric and Oceanic Sciences, \\ School of Physics, Peking University, Beijing 100871, China \\ ${ }^{2}$ State Key Laboratory of Atmospheric Boundary Layer Physics and Atmospheric Chemistry (LAPC), \\ Institute of Atmospheric Physics, Chinese Academy of Sciences, Beijing 100029, China \\ ${ }^{3}$ Program in Atmospheric and Oceanic Sciences, Princeton University, Princeton, New Jersey 08540, USA \\ ${ }^{4}$ Department of Mechanical Engineering, University of Colorado, Boulder, Colorado 80309, USA
}

Correspondence to: L. Zhang (zhanglg@pku.edu.cn)

Received: 27 February 2015 - Published in Atmos. Chem. Phys. Discuss.: 12 May 2015

Revised: 5 September 2015 - Accepted: 7 September 2015 - Published: 30 September 2015

\begin{abstract}
Rapid Asian industrialization has led to increased downwind atmospheric nitrogen deposition threatening the marine environment. We present an analysis of the sources and processes controlling atmospheric nitrogen deposition to the northwestern Pacific, using the GEOS-Chem global chemistry model and its adjoint model at $1 / 2^{\circ} \times 2 / 3^{\circ}$ horizontal resolution over East Asia and its adjacent oceans. We focus our analyses on the marginal seas: the Yellow Sea and the South China Sea. Asian nitrogen emissions in the model are $28.6 \mathrm{Tg} \mathrm{Na}^{-1}$ as $\mathrm{NH}_{3}$ and $15.7 \mathrm{Tg} \mathrm{Na}^{-1}$ as $\mathrm{NO}_{x}$. China has the largest sources with $12.8 \mathrm{Tg} \mathrm{N} \mathrm{a}^{-1}$ as $\mathrm{NH}_{3}$ and 7.9 $\mathrm{Tg} \mathrm{Na}^{-1}$ as $\mathrm{NO}_{x}$; the high- $\mathrm{NH}_{3}$ emissions reflect its intensive agricultural activities. We find Asian $\mathrm{NH}_{3}$ emissions are a factor of 3 higher in summer than winter. The model simulation for 2008-2010 is evaluated with $\mathrm{NH}_{3}$ and $\mathrm{NO}_{2}$ column observations from satellite instruments, and wet deposition flux measurements from surface monitoring sites. Simulated atmospheric nitrogen deposition to the northwestern Pacific ranges $0.8-20 \mathrm{~kg} \mathrm{Nha}^{-1} \mathrm{a}^{-1}$, decreasing rapidly downwind of the Asian continent. Deposition fluxes average $11.9 \mathrm{~kg} \mathrm{Nha}^{-1} \mathrm{a}^{-1}$ (5.0 as reduced nitrogen $\mathrm{NH}_{x}$ and 6.9 as oxidized nitrogen $\mathrm{NO}_{y}$ ) to the Yellow Sea, and $5.6 \mathrm{~kg}$ $\mathrm{Nha}^{-1} \mathrm{a}^{-1}\left(2.5\right.$ as $\mathrm{NH}_{x}$ and 3.1 as $\mathrm{NO}_{y}$ ) to the South China Sea. Nitrogen sources over the ocean (ship $\mathrm{NO}_{x}$ and oceanic $\mathrm{NH}_{3}$ ) have little contribution to deposition over the Yellow Sea, about $7 \%$ over the South China Sea, and become important (greater than $30 \%$ ) further downwind. We find that the seasonality of nitrogen deposition to the northwestern $\mathrm{Pa}$ -
\end{abstract}

cific is determined by variations in meteorology largely controlled by the East Asian monsoon and in nitrogen emissions. The model adjoint further estimates that nitrogen deposition to the Yellow Sea originates from sources over China (92\% contribution) and the Korean peninsula (7\%), and by sectors from fertilizer use $(24 \%)$, power plants $(22 \%)$, and transportation (18\%). Deposition to the South China Sea shows source contribution from mainland China $(66 \%)$, Taiwan (20\%), and the rest (14\%) from the southeast Asian countries and oceanic $\mathrm{NH}_{3}$ emissions. The adjoint analyses also indicate that reducing Asian $\mathrm{NH}_{3}$ emissions would increase $\mathrm{NO}_{y}$ dry deposition to the Yellow Sea (28\% offset annually), limiting the effectiveness of $\mathrm{NH}_{3}$ emission controls on reducing nitrogen deposition to the Yellow Sea.

\section{Introduction}

Anthropogenic emissions of reactive nitrogen (or fixed nitrogen) have led to a rapid growth of nitrogen deposition to both land and marine ecosystems (Galloway et al., 2004; Duce et al., 2008; Liu et al., 2013). This additional input of nitrogen nutrient may enhance the primary production and carbon storage of the terrestrial biosphere (Pregitzer et al., 2008; Hyvonen et al., 2008). Excessive nitrogen deposition has been observed over sensitive ecosystems and can cause adverse effects including soil acidification and a reduction in plant biodiversity over land (Bowman et al., 2008; Stevens 
et al., 2004), and eutrophication on lakes and oceans (Bouwman et al., 2002).

The northwestern Pacific is a region vulnerable to atmospheric nitrogen deposition as its productivity is generally limited by the low nutrient supply from deep water (Duce et al., 2008; Kim et al., 2011, 2014). Frequent incidences of harmful algal blooms in the marginal seas of the Pacific Ocean, such as the Yellow Sea, have been of great concern (Hu et al., 2010). This region is subject to significant anthropogenic nitrogen deposition as it is located downwind of the Asian continent with high fixed nitrogen emissions from increasing human activities (Kurokawa et al., 2013; Luo et al., 2014). Increased nitrogen availability in waters of the northwestern Pacific has been observed in the past 30 years, most likely due to increasing deposition from the atmosphere (Kim et al., 2011). To alleviate the eutrophication conditions in the northwestern Pacific requires a better understanding of the sources and atmospheric processes controlling nitrogen deposition to the region. Here we use a nested global chemical transport model (GEOS-Chem) and its adjoint to study the issue.

Atmospheric nitrogen deposition mainly originates from emissions of ammonia $\left(\mathrm{NH}_{3}\right)$ and nitrogen oxides $\left(\mathrm{NO}_{x} \equiv \mathrm{NO}+\mathrm{NO}_{2}\right) . \mathrm{NO}_{x}$ sources include fuel combustion, lightning, and microbial processes in soil. It can be oxidized to nitric acid $\left(\mathrm{HNO}_{3}\right)$ and organic nitrates in the atmosphere on a timescale less than 1 day except in extratropical winter (1-2 days) (Martin et al., 2003). $\mathrm{HNO}_{3}$ is water-soluble and is readily removed from the atmosphere by both wet and dry deposition. $\mathrm{NH}_{3}$ is mainly produced by agricultural activities (fertilizer use and manure management), human waste, as well as natural sources such as oceanic emissions (Bouwman et al., 1997). Reacting with sulfuric acid $\left(\mathrm{H}_{2} \mathrm{SO}_{4}\right)$ and $\mathrm{HNO}_{3}, \mathrm{NH}_{3}$ forms ammonium sulfate and ammonium nitrate particles in the atmosphere. The formation of ammonium particles increases the lifetime of nitrogen in the atmosphere, promoting its long-range transport as dry removal of particles is slow.

Globally, a large fraction $(\sim 40 \%)$ of emitted $\mathrm{NH}_{3}$ and $\mathrm{NO}_{x}$ enters the ocean via wet and dry deposition from the atmosphere, and the rest $(\sim 60 \%)$ is deposited over the land (Duce et al., 2008). Inputs from rivers provide additional fixed nitrogen to the ocean, but it is estimated that much of the riverine nitrogen is lost by denitrification in continental shelves and has a smaller impact on the open ocean (Seitzinger et al., 2006; Duce et al., 2008). Sanderson et al. (2008) showed using multiple models that about $10-15 \%$ of the emitted $\mathrm{NO}_{x}$ is exported out of East Asia as nitrogen oxides $\left(\mathrm{NO}_{y} \equiv \mathrm{NO}_{x}+\mathrm{HNO}_{3}+\right.$ aerosol $\mathrm{NO}_{3}^{-}+\mathrm{PAN}+\mathrm{N}_{2} \mathrm{O}_{5}+$ isoprene nitrates) with $34-49 \%$ of them deposited within $1000 \mathrm{~km}$ range. A number of studies have examined the processes of Asian pollution transport to the Pacific (Liu et al., 2003; Liang et al., 2004; Dickerson et al., 2007). Few studies have been conducted to quantify the patterns, processes, and source attribution of atmospheric nitrogen deposition to the northwestern Pacific.

We use the nested version of GEOS-Chem global chemical transport model (CTM) and its adjoint model with a horizontal resolution of $1 / 2^{\circ} \times 2 / 3^{\circ}$ (Chen et al., 2009; Jiang et al., $2015)$ to investigate the factors controlling atmospheric nitrogen deposition to the northwestern Pacific, particularly over the Yellow Sea and the South China Sea. A 3-year (20082010) GEOS-Chem model simulation is conducted to quantify the deposition processes and to understand the impact of meteorology on the seasonal variability of atmospheric deposition. We evaluate the model simulation with surface measurements of wet deposition fluxes and satellite observations of $\mathrm{NH}_{3}$ and $\mathrm{NO}_{2}$ columns. We further use the adjoint method to ascribe nitrogen deposition to the Yellow Sea and the South China Sea to nitrogen sources from different regions and sectors.

\section{The GEOS-Chem model and its adjoint}

\subsection{General description}

We use a nested version of the GEOS-Chem 3-D global CTM (Chen et al., 2009; Zhang et al., 2012, 2014; http: //geos-chem.org) driven by GEOS-5 (Goddard Earth Observing System) assimilated meteorological data from NASA's Global Modeling and Assimilation Office (GMAO). The GEOS-5 meteorological data have a temporal resolution of $6 \mathrm{~h}$ ( $3 \mathrm{~h}$ for surface variables and mixing layer depths), a horizontal resolution of $1 / 2^{\circ}$ latitude $\times 2 / 3^{\circ}$ longitude, and 72 layers in the vertical. We use the native $1 / 2^{\circ} \times 2 / 3^{\circ}$ horizontal resolution over East Asia and its adjacent oceans (70$150^{\circ} \mathrm{E}, 11^{\circ} \mathrm{S}-55^{\circ} \mathrm{N}$ ), and $4^{\circ} \times 5^{\circ}$ over the rest of the world. We present results from a 3-year GEOS-Chem simulation for 2008-2010. A global $4^{\circ} \times 5^{\circ}$ simulation is first conducted to provide the boundary conditions for the nested model at $3 \mathrm{~h}$ temporal resolution. Simulations are initialized on $1 \mathrm{Jan}-$ uary 2008 with model fields generated by a 6 -month spin-up run at both $4^{\circ} \times 5^{\circ}$ and nested resolutions.

Zhang et al. (2012) have applied a similar nested model for North America to analyze the sources and processes of nitrogen deposition to the USA. The model includes a fully coupled tropospheric ozone- $\mathrm{NO}_{x}$-hydrocarbon-aerosol chemical mechanism (Bey et al., 2001; Park et al., 2004; Mao et al., 2010). Partitioning of gas and aerosol phase of total $\mathrm{NH}_{3}$ and $\mathrm{HNO}_{3}$ is calculated using the ISORROPIA II thermodynamic equilibrium model (Fountoukis and Nenes, 2007). Following Zhang et al. (2012), we assume that isoprene nitrates produced from the oxidation of biogenic isoprene are removed by dry and wet deposition at the same rate as $\mathrm{HNO}_{3}$. The reactive uptake coefficients for dinitrogen dentoxide $\left(\mathrm{N}_{2} \mathrm{O}_{5}\right)$ in aerosols are from Evans and Jacob (2005), but are reduced by a factor of 10 as in Zhang et al. (2012). 
Table 1. Monthly mean daytime dry deposition velocities over the northwestern Pacific ${ }^{\mathrm{a}}$.

\begin{tabular}{lcccc}
\hline & January & April & July & October \\
\hline $\mathrm{NH}_{3}$ & 1.10 & 0.70 & 0.60 & 0.85 \\
Aerosol NH$_{4}^{+}$ & 0.08 & 0.06 & 0.06 & 0.07 \\
$\mathrm{HNO}_{3}$, isoprene nitrates $^{\mathrm{b}}$ & 1.16 & 0.69 & 0.56 & 0.84 \\
$\mathrm{Aerosol} \mathrm{NO}_{3}^{-}$ & 0.08 & 0.06 & 0.06 & 0.07 \\
$\mathrm{~N}_{2} \mathrm{O}_{5}$ & 1.16 & 0.69 & 0.56 & 0.84 \\
$\mathrm{NO}_{2}$ & 0.01 & 0.01 & 0.01 & 0.01 \\
$\mathrm{PANs}^{\mathrm{c}}$ & 0.01 & 0.01 & 0.01 & 0.01 \\
\hline
\end{tabular}

${ }^{a}$ Numbers are in units of $\mathrm{cm} \mathrm{s}^{-1}$ and averaged over 2008-2010. ${ }^{\mathrm{b}}$ Isoprene nitrates represent the organic nitrates produced from the oxidation of isoprene by $\mathrm{OH}$ in the presence of $\mathrm{NO}_{x} \cdot{ }^{\mathrm{c}}$ Peroxyacetyl nitrate (PAN) and higher peroxyacyl nitrates.

Model parameterization of wet deposition via both convective updraft and large-scale precipitation scavenging follows the scheme described by Liu et al. (2001) for aerosol, and by Mari et al. (2000) and Amos et al. (2012) for soluble gas. Dry deposition calculation follows a standard big-leaf resistance-in-series model (Wesely, 1989) including the aerodynamic resistance, the boundary layer resistance, and the canopy or surface uptake resistance. Dry deposition velocities are calculated relative to the lowest model layer ( $\sim 70 \mathrm{~m}$ above the surface) as discussed in Zhang et al. (2012). The GEOS-5 data have a low bias for nighttime planetary boundary layer height (PBLH). This has been corrected by setting a minimum PBLH computed as a function of local friction velocity (Koracin and Bberkowicz, 1988; Sajeev Philip; http://wiki.seas.harvard.edu/geos-chem/index. php/Boundary_layer_mixing).

Table 1 summarizes the model calculation of monthly mean daytime (10:00-16:00 LT) dry deposition velocities for different nitrogen species over the northwestern Pacific. Calculated dry deposition velocities are the largest for $\mathrm{HNO}_{3}$, $\mathrm{N}_{2} \mathrm{O}_{5} \quad\left(0.56-1.16 \mathrm{~cm} \mathrm{~s}^{-1}\right)$ and $\mathrm{NH}_{3} \quad\left(0.60-1.10 \mathrm{~cm} \mathrm{~s}^{-1}\right)$, $0.06-0.08 \mathrm{~cm} \mathrm{~s}^{-1}$ for aerosol ammonium $\left(\mathrm{NH}_{4}^{+}\right)$and nitrate $\left(\mathrm{NO}_{3}^{-}\right)$, and near zero for insoluble species such as nitrogen dioxide $\left(\mathrm{NO}_{2}\right)$ and Peroxyacetyl nitrate (PAN). The values are generally much smaller than those over land (e.g., Table 1 of Zhang et al., 2012) as the uptake resistance over the smooth ocean surface is high. Deposition velocities are higher in winter than those in summer due to stronger winds near the ocean surface in winter.

The model calculated dry deposition velocities for aerosols are consistent with the mean value of $0.1 \mathrm{~cm} \mathrm{~s}^{-1}$ (with a range of $0.03-0.3 \mathrm{~cm} \mathrm{~s}^{-1}$ ), estimated by Duce et al. (1991) for aerosol dry deposition over the ocean surface. For gaseous $\mathrm{NH}_{3}$ and $\mathrm{HNO}_{3}$, Zhang et al. (2010) estimated similar dry deposition velocities $\left(0.5-0.85 \mathrm{~cm} \mathrm{~s}^{-1}\right)$ over eastern China seas in spring-fall using the MM5/CMAQ model (Community Multi-scale Air Quality driven by the PSU/NCAR Mesoscale Model), but suggested minimum deposition velocities in winter $\left(\sim 0.5 \mathrm{~cm} \mathrm{~s}^{-1}\right.$ versus 1.10
$1.16 \mathrm{~cm} \mathrm{~s}^{-1}$ in our estimates). Understanding this discrepancy would require a close examination of differences between the two studies, such as different simulation years and different air-sea roughness parameterizations in the two models. Zhang et al. (2010) modified the sea-surface roughness length by considering the impact of sea-surface height, while GEOS-5 used in this study follows the MoninObukhov similarity theory with improved parameters to match recent air-sea exchange observations (Garfinkel et al., 2011).

\subsection{Emissions}

Global anthropogenic emissions $\left(\mathrm{NO}_{x}, \mathrm{SO}_{2}, \mathrm{CO}\right.$, and nonmethane volatile organic compounds (VOCs) are from the Emission Database for Global Atmospheric Research (EDGAR) inventory (Olivier and Berdowski, 2001) except for global anthropogenic $\mathrm{NH}_{3}$ emissions that are taken from the Global Emissions InitiAtive (GEIA) inventory (Bouwman et al., 1997). Regional emission inventories are then applied including the European Monitoring and Evaluation Programme (EMEP) inventory (Vestreng and Klein, 2002) over Europe, the EPA 2005 National Emissions Inventory (NEI-2005) over the USA, the Canada Criteria Air Contaminants (CAC) inventory (http://www.ec.gc.ca/pollution/ default.asp?lang=_En\&n=E96450C4-1) over Canada, and the Regional Emission in Asia (REAS-v2) inventory for 2008 (Kurokawa et al., 2013) over Asia (with updates for $\mathrm{NH}_{3}$ emissions as described below). Global ship $\mathrm{NO}_{x}$ emissions are from the International Comprehensive Ocean-Atmosphere Data Set (ICOADS) (Wang et al., 2008). The emitted $\mathrm{NO}_{x}$ from ships is directly converted into $\mathrm{HNO}_{3}$ and ozone to account for their rapid chemistry at a sub-grid scale (Vinken et al., 2011).

The model also includes various natural sources of $\mathrm{NH}_{3}$ and $\mathrm{NO}_{x}$. Lightning $\mathrm{NO}_{x}$ emissions are calculated using the cloud top height parameterization of Price and Rind (1992), vertically distributed following Pickering et al. (1998), and further spatially constrained with satellite observations as described by Sauvage (2007) and Murray et al. (2012). The global lightning source is adjusted to be $6 \mathrm{Tg} \mathrm{Na}^{-1}$ (Martin et al., 2007). Soil emissions are computed by the algorithm Yienger and Levy (1995) with canopy reduction factors (Wang et al., 1998). Biomass burning emissions of $\mathrm{NO}_{x}$ and $\mathrm{NH}_{3}$ are from the Global Fire Emissions Database version 2 (GFED-v2) inventory (van der Werf et al., 2006). Natural $\mathrm{NH}_{3}$ emissions include both terrestrial and ocean emissions from the GEIA inventory (Bouwman et al., 1997).

The REAS-v2 emission inventory is estimated based on activity data and emission factors separated by different source categories (Kurokawa et al., 2013). Major $\mathrm{NO}_{x}$ sources include fuel combustion in power plants, industry, transport and domestic sectors, and $\mathrm{NH}_{3}$ sources are mainly from fertilizer use and manure management of livestock and human waste (Kurokawa et al., 2013). The sectorial informa- 

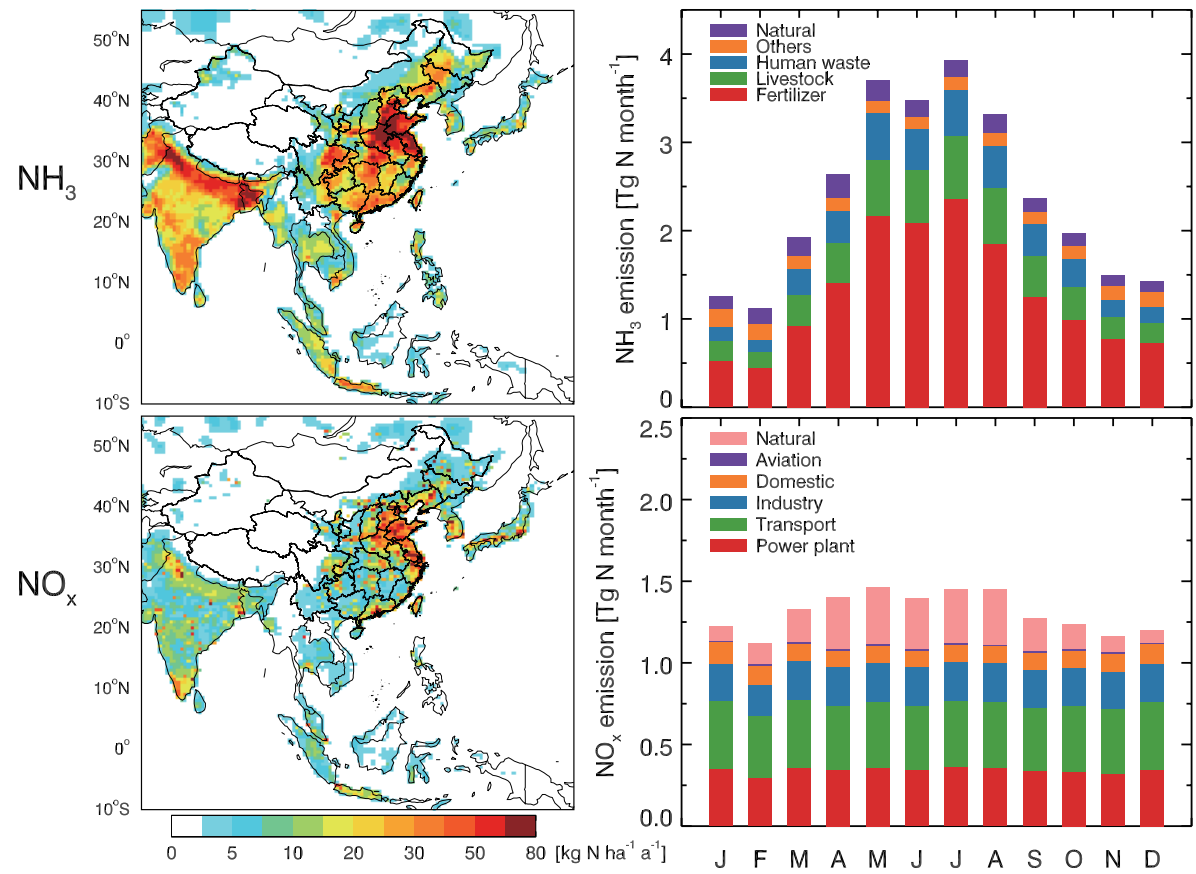

Figure 1. Asian $\mathrm{NH}_{3}$ and $\mathrm{NO}_{x}$ emissions in 2008-2010. The left panels show annual total emissions and the right panels show monthly values of $\mathrm{NH}_{3}$ and $\mathrm{NO}_{x}$ emissions from each source type over Asia.

tion allows us to quantify nitrogen deposition contributions from different source categories in the adjoint analysis as discussed in Sect. 5.

The REAS-v2 $\mathrm{NH}_{3}$ inventory consists of constant annual emissions without any seasonal variation (Kurokawa et al., 2013). Here we keep the annual total $\mathrm{NH}_{3}$ emissions from REAS-v2 and derive monthly scalars over each model grid cell for $\mathrm{NH}_{3}$ from different sectors (fertilizer use, livestock, and human waste). $\mathrm{NH}_{3}$ emissions from fertilizer use are controlled by soil properties, meteorology, and the timing of fertilizer application. We follow the method and formula given in Skjøth et al. (2011) and Paulot et al. (2014). We consider nine types of crops (early rice/late rice, winter wheat/spring wheat, maize, cotton, sweet potatoes, potatoes, fruit and vegetables) with the harvest areas given by Monfreda et al. (2008). The growth cycles of those crops and their fertilizer inputs at different application times are based on Liao (1993) and Sacks et al. (2010). For $\mathrm{NH}_{3}$ emissions from livestock and human waste, we use the temperaturedependent experimental formula from Aneja et al. (2000). For the diurnal variability, the $\mathrm{NH}_{3}$ agricultural emissions are increased by $90 \%$ during the day and reduced by $90 \%$ at night following Zhu et al. (2013). Here we have not considered air-surface bi-directional exchange of $\mathrm{NH}_{3}$ (Sutton et al., 1998), and treat the $\mathrm{NH}_{3}$ fluxes as uncoupled emission and deposition processes.

Figure 1 shows the spatial distribution of annual total $\mathrm{NH}_{3}$ and $\mathrm{NO}_{x}$ emissions over Asia. Monthly $\mathrm{NH}_{3}$ and $\mathrm{NO}_{x}$ emissions from different source types over this region are also
Table 2. Annual total $\mathrm{NH}_{3}$ and $\mathrm{NO}_{x}$ emissions over Asia and China $^{\mathrm{a}}$.

\begin{tabular}{|c|c|c|c|}
\hline & Source type & Asia & China \\
\hline \multirow[t]{6}{*}{$\mathrm{NH}_{3}$} & Fertilizer & 15.5 & 7.8 \\
\hline & Livestock & 5.1 & 2.4 \\
\hline & Human waste & 4.0 & 1.5 \\
\hline & Others ${ }^{b}$ & 1.8 & 0.7 \\
\hline & Natural $^{\mathrm{c}}$ & $2.1(0.5)^{\mathrm{d}}$ & 0.5 \\
\hline & Total & 28.6 & 12.8 \\
\hline \multirow[t]{6}{*}{$\mathrm{NO}_{x}$} & Power plants & 4.1 & 2.8 \\
\hline & Transport & 4.8 & 1.8 \\
\hline & Industry & 2.8 & 2.0 \\
\hline & Domestic & 1.3 & 0.7 \\
\hline & Natural $^{\mathrm{e}}$ & 2.6 & 0.7 \\
\hline & Total & 15.7 & 7.9 \\
\hline \multicolumn{4}{|c|}{$\begin{array}{l}\text { a Annual emissions in unit of } \mathrm{Tg} \mathrm{Na}^{-1} \text { for } 2008-2010 . \\
\text { b Other anthropogenic sources include ammonia emissions } \\
\text { from power plant, transport, industry, and domestic emission. } \\
{ }^{c} \text { Natural } \mathrm{NH}_{3} \text { emissions include emissions from natural } \\
\text { terrestrial and ocean. }{ }^{\mathrm{d}} \text { Annual } \mathrm{NH}_{3} \text { oceanic emissions over } \\
\text { this region. }{ }^{\mathrm{e}} \text { Natural } \mathrm{NO}_{x} \text { emissions include emissions from } \\
\text { soil, lightning and biomass burning. }\end{array}$} \\
\hline
\end{tabular}

shown in Fig. 1 and the annual totals for Asia and China are summarized in Table 2. The largest $\mathrm{NH}_{3}$ emissions are over eastern China and India with values over $50 \mathrm{~kg} \mathrm{Nha}^{-1} \mathrm{a}^{-1}$. We estimate strong seasonality for the $\mathrm{NH}_{3}$ emissions from fertilizer use mainly determined by its usage timing, and from livestock and human waste depending on surface tem- 
perature. Asian $\mathrm{NH}_{3}$ emissions are the highest in MayAugust, and a factor of 3 higher than emissions in winter, similar to the seasonality of US $\mathrm{NH}_{3}$ emissions in Zhang et al. (2012) derived by $\mathrm{NH}_{x}\left(\mathrm{NH}_{3}\right.$ gas + aerosol $\left.\mathrm{NH}_{4}^{+}\right)$surface concentration measurements and in Zhu et al. (2013) constrained by Tropospheric Emissions Spectrometer (TES) $\mathrm{NH}_{3}$ observations. Natural $\mathrm{NH}_{3}$ emissions account for $5 \%$ of the total Asian $\mathrm{NH}_{3}$ emissions in summer, $11 \%$ in winter, and $7 \%$ annually; $24 \%$ of the natural $\mathrm{NH}_{3}$ emissions are from the oceanic emissions $\left(0.50 \mathrm{Tg} \mathrm{N} \mathrm{a}^{-1}\right)$ over the region. Recent studies suggested that the GEIA $\mathrm{NH}_{3}$ oceanic emissions were too high (Paulot et al., 2015). Anthropogenic $\mathrm{NO}_{x}$ emissions show weak seasonal variation, consistent with other emission estimates (Streets et al., 2003; Zhang et al., 2009). Natural $\mathrm{NO}_{x}$ emissions (lightning, soil, and biomass burning) account for $23 \%$ of the total Asian $\mathrm{NO}_{x}$ emissions in summer, $8 \%$ in winter, and $16 \%$ annually.

Annual $\mathrm{NH}_{3}$ and $\mathrm{NO}_{x}$ emissions over China are, respectively, 12.8 and $7.9 \mathrm{Tg} \mathrm{N} \mathrm{a}^{-1}$ (REAS-v2 anthropogenic and natural emissions). Our $\mathrm{NH}_{3}$ emissions are at the high end of the range of $7.9-13.2 \mathrm{Tg} \mathrm{N} \mathrm{a}^{-1}$ in the published Chinese $\mathrm{NH}_{3}$ emission estimates (Streets et al., 2003; Dong et al., 2010; Paulot et al., 2014, and references therein). This is mainly attributed to a higher estimate of $\mathrm{NH}_{3}$ from fertilizer use in REAS-v2 $\left(7.8 \mathrm{Tg} \mathrm{N} \mathrm{a}^{-1}\right)$ than other emission inventories (e.g., 3.2 $\mathrm{Tg} \mathrm{N} \mathrm{a}^{-1}$ in Huang et al., 2012). The successful simulation of $\mathrm{NH}_{3}$ column concentrations and ammonium wet deposition fluxes as described below lends support to the high Chinese $\mathrm{NH}_{3}$ emissions. Compared with nitrogen emissions in the USA $\left(2.9 \mathrm{Tg} \mathrm{N} \mathrm{a}^{-1}\right.$ as $\mathrm{NH}_{3}$, and $6.3 \mathrm{Tg} \mathrm{N} \mathrm{a}^{-1}$ as $\mathrm{NO}_{x}$ ) (Zhang et al., 2012), $\mathrm{NH}_{3}$ emissions in China are a factor of 4 higher, reflecting its high levels of agricultural activities as well as the population.

\subsection{The adjoint model}

The adjoint method provides an efficient way to calculate the sensitivity of model variables (e.g., concentrations and deposition fluxes) to model parameters (e.g., emissions). Here we briefly describe the adjoint method, and more details are given in Henze et al. (2007). Mathematically, the GEOSChem model can be viewed as a numerical operator $\mathbf{F}$ : $\boldsymbol{y}_{n+1}=\mathbf{F}\left(\boldsymbol{y}_{n}, \boldsymbol{x}\right)$, where $\boldsymbol{y}_{n}$ is the vector of concentrations at time step $n$, and $\boldsymbol{x}$ is the vector of model parameters such as emissions. If we define a model response function, $J$ (e.g., model deposition), and let $\lambda_{x}^{n}=\left(\frac{\partial J}{\partial \boldsymbol{x}_{n}}\right)^{T}$ and $\lambda_{y}^{n}=\left(\frac{\partial J}{\partial \boldsymbol{y}_{n}}\right)^{T}$, then $\lambda_{x}^{0}=\nabla_{x} J$ represents the sensitivity of $J$ to model parameters, and $\lambda_{y}^{0}=\nabla_{y 0} J$ represents its sensitivity to the initial conditions. In the adjoint model these are computed simultaneously backwards:

$\lambda_{y}^{n-1}=\left(\frac{\partial \mathbf{F}}{\partial \boldsymbol{y}}\left(\boldsymbol{y}_{n-1}, \boldsymbol{x}\right)\right)^{T} \lambda_{y}^{n}$, $\lambda_{x}^{n-1}=\left(\frac{\partial \mathbf{F}}{\partial \boldsymbol{x}}\left(\boldsymbol{y}_{n-1}, \boldsymbol{x}\right)\right)^{T} \lambda_{y}^{n}+\lambda_{x}^{n}$,

where $\left(\frac{\partial \mathbf{F}}{\partial \boldsymbol{y}}\left(\boldsymbol{y}_{n-1}, \boldsymbol{x}\right)\right)^{T}$ and $\left(\frac{\partial \mathbf{F}}{\partial \boldsymbol{x}}\left(\boldsymbol{y}_{n-1}, \boldsymbol{x}\right)\right)^{T}$ are the transpose of the model Jacobian matrix.

The adjoint of GEOS-Chem was constructed by Henze et al. (2007) for constraining aerosol sources, and extended by Kopacz et al. (2009) for inverse estimates of CO sources. The GEOS-Chem adjoint explicitly includes transport components (advection, boundary layer mixing, and convection), gas-phase chemistry, and heterogeneous chemistry (Henze et al., 2007, 2009). The adjoint of the ISORROPIA aerosol thermodynamic equilibrium model was constructed by Capps et al. (2012).

The GEOS-Chem adjoint model has been evaluated and applied in a number of studies, including optimizing aerosol emission (Henze et al., 2009; Zhu et al., 2013), attributing sources of ozone pollution in the western USA (Zhang et al., 2009), and quantifying processes affecting nitrogen deposition to biodiversity hotspots worldwide (Paulot et al., 2013, 2014). Those studies used the adjoint model at global $4^{\circ} \times 5^{\circ}$ or $2^{\circ} \times 2.5^{\circ}$ resolution. The adjoint of the nested-grid GEOSChem has been developed by Jiang et al. (2015) and Zhang et al. (2015), and applied to constrain black carbon emissions (Mao et al., 2015) and assess human exposure to equatorial Asian fires (Kim et al., 2015). Here we apply it to quantify sources contributing to atmospheric nitrogen deposition over the northwestern Pacific.

\section{Column concentrations and wet deposition fluxes over Asia}

We compare model simulation of $\mathrm{NH}_{3}$ tropospheric columns with satellite measurements from the TES (Beer, 2006), and $\mathrm{NO}_{2}$ tropospheric columns with those from the ozone monitoring instrument (OMI) (Levelt et al., 2006). Both are aboard the NASA Aura satellite in a sun-synchronous orbit with an ascending equator crossing time of 13:45 LT (Beer, 2006). We evaluate model simulated wet deposition fluxes of ammonium and nitrate with observational data from the Acid Deposition Monitoring Network in East Asia (EANET; data available at http://www.eanet.asia/index.html) and 10 sites monitored by the Chinese Academy of Science (CAS) located in North China (Pan et al., 2012). Measurements of nitrogen dry deposition fluxes are rather limited over the northwestern Pacific.

Figure 2 compares GEOS-Chem simulated $\mathrm{NH}_{3}$ and $\mathrm{NO}_{2}$ tropospheric columns with satellite measurements. These comparisons provide valuable tests of the nitrogen emissions and their spatial distributions in the model since both $\mathrm{NH}_{3}$ and $\mathrm{NO}_{2}$ have short lifetimes in the atmosphere. Although $\mathrm{NO}_{2}$ has a small dry deposition velocity (Table 1), it rapidly converts to other $\mathrm{NO}_{y}$ species; thus $\mathrm{NO}_{2}$ emissions still largely control the deposition of $\mathrm{NO}_{y}$. 

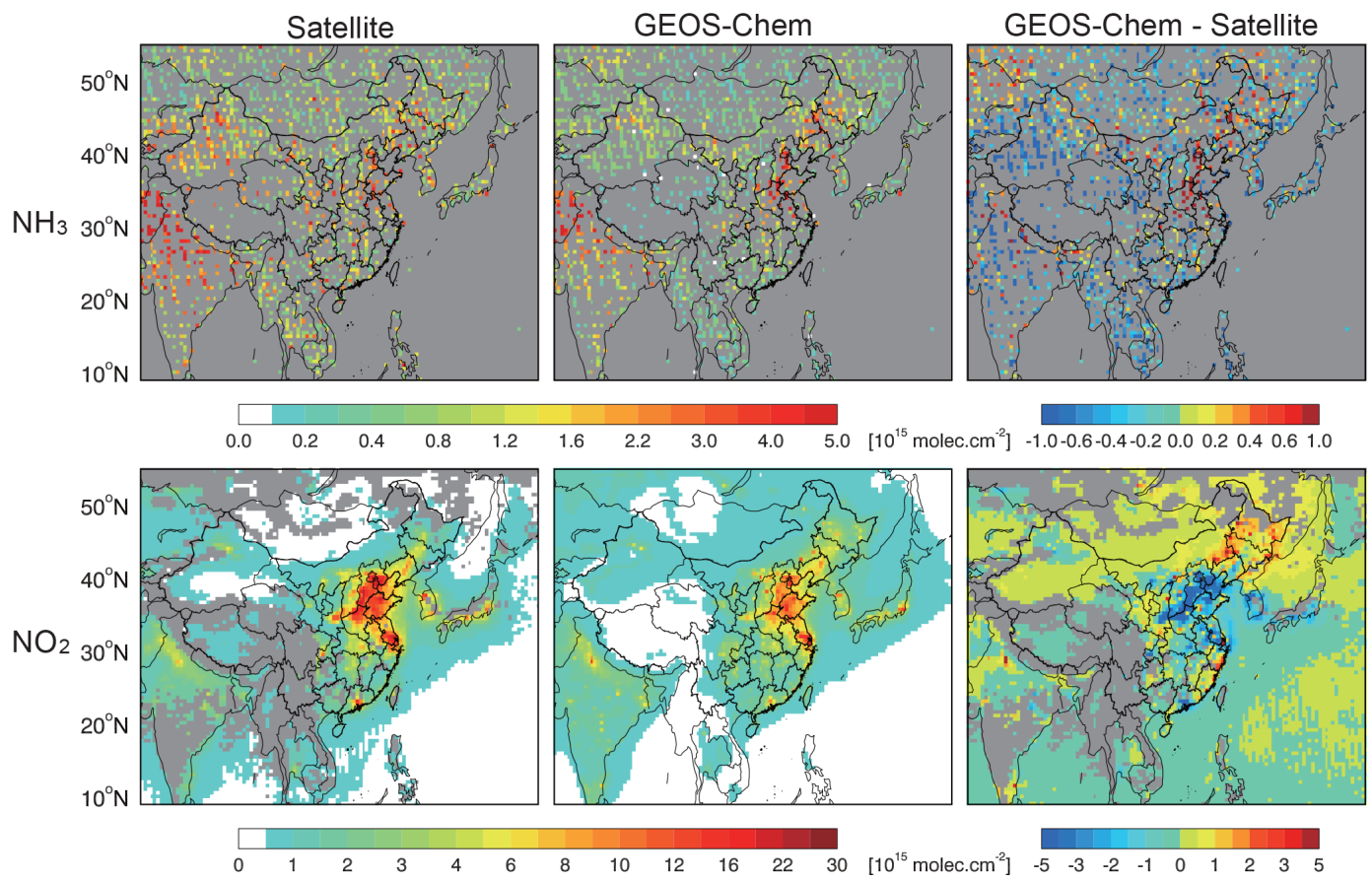

Figure 2. Satellite observations of $\mathrm{NH}_{3}$ tropospheric columns from TES (top left) and $\mathrm{NO}_{2}$ tropospheric columns from ozone monitoring instrument (OMI) (bottom left). The TES observations are daytime measurements during June-August 2005-2010. The OMI observations during March-November 2009 are from KNMI at $0.125^{\circ} \times 0.125^{\circ}$ resolution. Both are re-grided to the model resolution $\left(1 / 2^{\circ} \times 2 / 3^{\circ}\right)$. The middle panels show corresponding GEOS-Chem model results for 2009 sampled at the satellite overpass time (13:45 LT). The right panels show the GEOS-Chem minus satellite differences.

The top panels of Fig. 2 compare TES measured and GEOS-Chem simulated $\mathrm{NH}_{3}$ tropospheric columns in summer (June-August). TES is an infrared Fourier transform spectrometer with a high spectral resolution of $0.06 \mathrm{~cm}^{-1}$ (Beer, 2006). The observations have a spatial resolution of $5 \mathrm{~km} \times 8 \mathrm{~km}$ with global coverage achieved in 16 days. $\mathrm{NH}_{3}$ retrievals from TES are based on the optimal estimation method of Rodgers (2000), as described by Shephard et al. (2011). Following Zhu et al. (2013) that used TES $\mathrm{NH}_{3}$ observations to optimize the US $\mathrm{NH}_{3}$ emissions, we filter the TES observations based on the retrieval quality control flags, and only use the daytime observations with a cloud optical depth < 1.0. We use TES observations in summer as they generally have the highest sensitivities during the year (Shephard et al., 2011), and use observations collected from 2005 to 2010 to increase the number of observations for comparison. The GEOS-Chem model results for 2009 are sampled along the TES orbit tracks at the overpass time (the standard TES products are level-2 data due to the sparse daily spatial coverage), and then applied with the TES retrieval operator following Zhang et al. (2006) and Zhu et al. (2013). As shown in Fig. 2, the model generally captures the observed high- $\mathrm{NH}_{3}$ columns over North and northeast China, and India (correlation coefficient $r=0.53$ ). The model largely underestimates $\mathrm{NH}_{3}$ columns over India by $28 \%$, which suggests $\mathrm{NH}_{3}$ emis- sions over India are too low. For observations over China, the model only has a small negative bias of $3 \%$.

The bottom panels of Fig. 2 compare OMI measured and GEOS-Chem simulated $\mathrm{NO}_{2}$ tropospheric columns averaged over March-November 2009. OMI measures backscattered solar radiation over the $270-500 \mathrm{~nm}$ wavelength range, and has a spatial resolution of $13 \mathrm{~km} \times 24 \mathrm{~km}$ and daily global coverage (Levelt et al., 2006). We use the Dutch OMI (DOMINO) v2.0 $\mathrm{NO}_{2}$ data from the Royal Netherlands Meteorological Institute (KNMI; Boersma et al., 2011; http://www.temis.nl/). To facilitate the comparison we use the monthly gridded tropospheric $\mathrm{NO}_{2}$ column data which are averages of the retrievals with a cloud radiance fraction $<50 \%$ (http://www.temis.nl/docs/readme tomsascii.pdf). The DOMINO $\mathrm{NO}_{2}$ data have been validated against surface and aircraft observations (Boersma et al., 2008, 2009; Hains et al., 2010; Ma et al., 2013), and used to constrain $\mathrm{NO}_{x}$ emissions in the model (Boersma et al., 2008; Lamsal et al., 2010). The wintertime measurements are excluded due to large retrieval errors over snow (O'Byrne et al., 2010). The model generally captures the observed distribution of $\mathrm{NO}_{2}$ tropospheric columns over Asia $(r=0.93)$, but it is biased low by $15 \%$ over North China on average. Recent studies have indicated that DOMINO $\mathrm{NO}_{2}$ columns might be biased high due to the a priori profile shape, error in the surface air-mass factor, and exclusion of aerosols in 

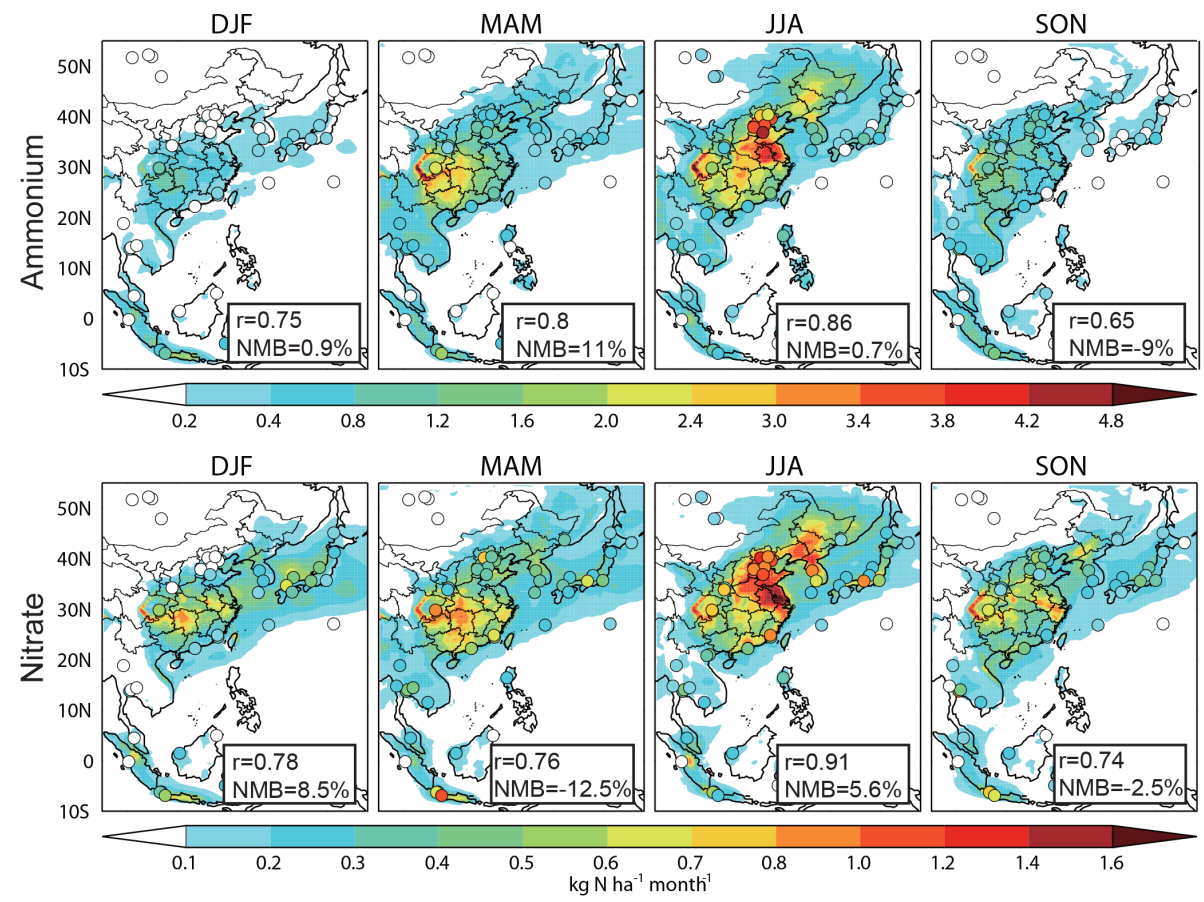

Figure 3. GEOS-Chem simulated seasonal mean ammonium (top panels) and nitrate (bottom panels) wet deposition fluxes for 2008-2010. The measurements from EANET (49 sites in the domain) and 10 CAS sites are over-plotted (circles). Correlation coefficients $(r)$ and mean normalized biases (NMB) are given inset. The EANET data and model results are averaged for January 2008-December 2010, and the CAS data are for December 2007-November 2010. DJF represents December-January-February, MAM: March-April-May, JJA: June-JulyAugust, SON: September-October-November.

the retrieval (Hains et al., 2010; Lamsal et al., 2010; Lin et al., 2014). The comparison also did not apply the averaging kernels to the model simulated columns, which may lead to additional biases when simulated $\mathrm{NO}_{2}$ vertical profiles are different from the a priori profiles used in the OMI retrievals (Huijnen et al., 2010).

We compare in Fig. 3 the observed vs. simulated seasonal mean ammonium and nitrate wet deposition fluxes at the EANET and CAS monitoring sites. The EANET data and model results are averaged for January 2008December 2010, and the CAS data are for December 2007November 2010. We compute the correlation coefficient and the normalized mean bias $\left(\mathrm{NMB}=\sum_{i=1}^{N}\left(M_{i}-O_{i}\right) / \sum_{i=1}^{N} O_{i}\right)$ between the observations $(O)$ and model results $(M)$ for the $N$ monitoring sites. The model simulation is in good agreement with the observations for both ammonium and nitrate wet deposition fluxes. For all seasons the correlation coefficients are greater than 0.7 and mean normalized biases (NMB) values are less than $15 \%$. Annually model simulated nitrogen wet deposition $\left(\mathrm{NH}_{4}^{+}+\mathrm{NO}_{3}^{-}\right)$ fluxes over China averages $9.3 \mathrm{~kg} \mathrm{~N} \mathrm{ha}^{-1} \mathrm{a}^{-1}$ with $\mathrm{NH}_{4}^{+}$contributing $70 \%$. Compared with previous studies using ensembles of surface measurements, our estimated annual nitrogen wet deposition over China is $\sim 30 \%$ lower than the estimates of $13.9 \mathrm{~kg} \mathrm{Nha}^{-1} \mathrm{a}^{-1}$ by Jia et al. (2014) and $13.2 \mathrm{~kg} \mathrm{Nha}^{-1} \mathrm{a}^{-1}$ by J. Zhu et al. (2015), but is consistent with $9.88 \mathrm{~kg} \mathrm{Nha}^{-1} \mathrm{a}^{-1}$ by Lv and Tian (2007). The $\mathrm{NH}_{4}^{+}$ contribution to wet deposition is higher than that estimated by J. Zhu et al. (2015) (55\%), but is consistent with Lv and Tian (2007) (72\%) and Pan et al. (2012) (63-78\% over North China).

Previous studies have shown that model simulation of wet deposition flux is highly sensitive to the model precipitation (Pinder et al., 2006; Paulot et al., 2014). We evaluate the GEOS-5 precipitation data over the northwestern $\mathrm{Pa}$ cific with data from the CPC Merged Analysis of Precipitation (CMAP). The CMAP data are based on several satellite measurements as described in Xie and Arkin (1997), and have a spatial resolution of $2.5^{\circ} \times 2.5^{\circ}$ and monthly variation (data available at http://www.cpc.ncep.noaa.gov/products/ global_precip/html/wpage.cmap.html). Figure 4 compares the monthly averaged GEOS-5 precipitation data with CMAP in January, April, July and October 2009. Both CMAP and GEOS-5 show maximum precipitation over the northwestern Pacific Ocean in July and minimum in January. The GEOS-5 precipitation data generally agree well with the CMAP data $(r=0.83-0.92)$, with only small negative biases of $2-5 \%$ over the ocean.

To focus on the northwestern Pacific, we further examine the measured and simulated nitrogen wet deposition fluxes at 

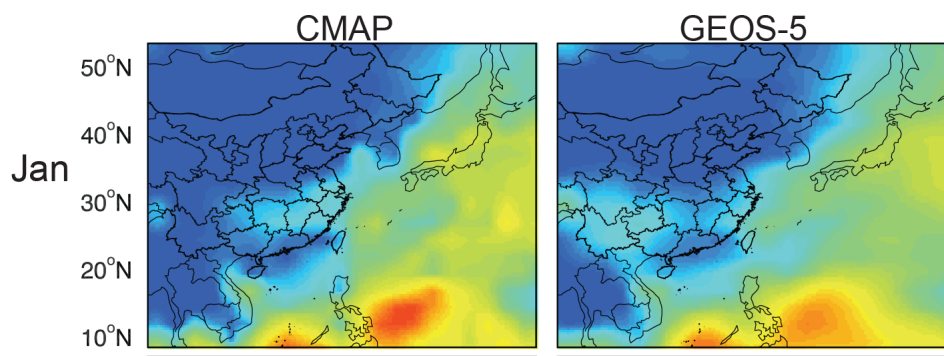

Precipitation over the Ocean
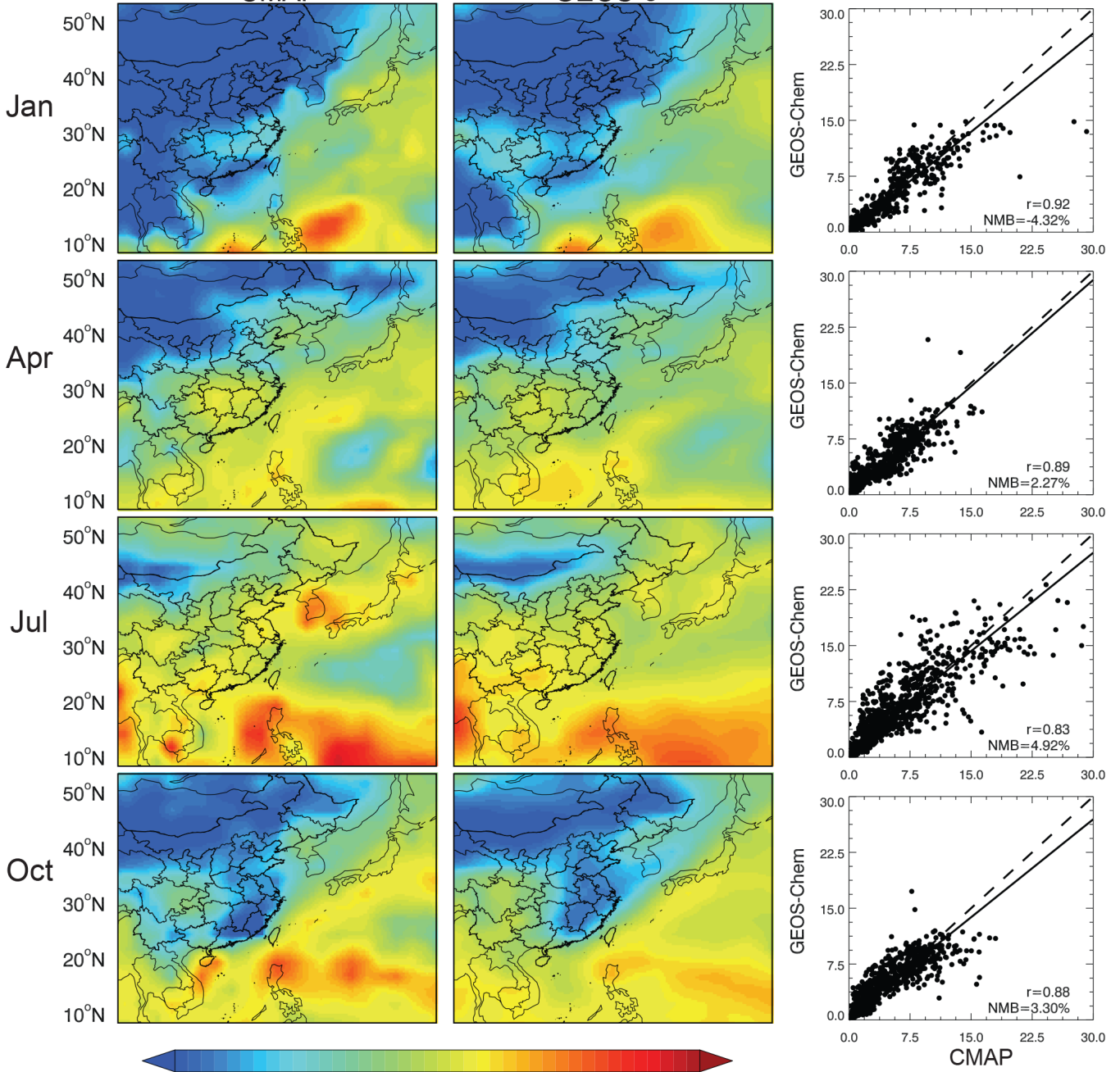

$\begin{array}{lllllllll}0.1 & 0.6 & 1.2 & 2.4 & 4.8 & 10 & 15 & 20 & 29 \\ {\left[\mathrm{~mm} \mathrm{day}^{-1}\right]}\end{array}$

Figure 4. Monthly mean precipitation data from CMAP (left panels) and from GEOS-5 (central panels) for January, April, July, and October 2009. The right panels show corresponding scatter plots of CMAP versus GEOS-5 precipitation over the northwestern Pacific Ocean. Correlation coefficients $(r)$ and mean normalized biases (NMB) are shown inset.

nine coastal EANET sites. Figure 5 shows locations of these monitoring sites and the focused region of this study. Figure 6 compares the observed vs. simulated monthly mean ammonium and nitrate wet deposition fluxes at the nine coastal sites. For the sites over the continent, both ammonium and nitrate wet deposition fluxes show summer maximum and winter minimum, consistent with seasonal variation of nitrogen emissions and precipitation. For the island sites in the open ocean (Cheju and Hedo), the deposition fluxes are much smaller with much weaker seasonal variations. Overall the model closely reproduces the magnitudes and variability of the measured wet deposition fluxes.

\section{Nitrogen deposition to the northwestern Pacific}

\subsection{Seasonal variation and deposition process}

We now examine the deposition processes, patterns, and seasonal variation of atmospheric nitrogen deposition to the northwestern Pacific. Figure 7 shows the spatial distribution of total nitrogen deposition (ammonium and nitrate, dry and wet) to the northwestern Pacific in January, April, July, and October, and Fig. 8 shows annual total deposition fluxes averaged over 2008-2010. Unlike the strong seasonality in nitrogen deposition over the Asian continent, deposition over the ocean has weaker seasonality as also shown by the wet deposition fluxes in Fig. 6. At low latitudes $\left(<30^{\circ} \mathrm{N}\right)$ or over the oceans east of Japan, we can see nitrogen deposition reaches its maximum in January and is the lowest in 


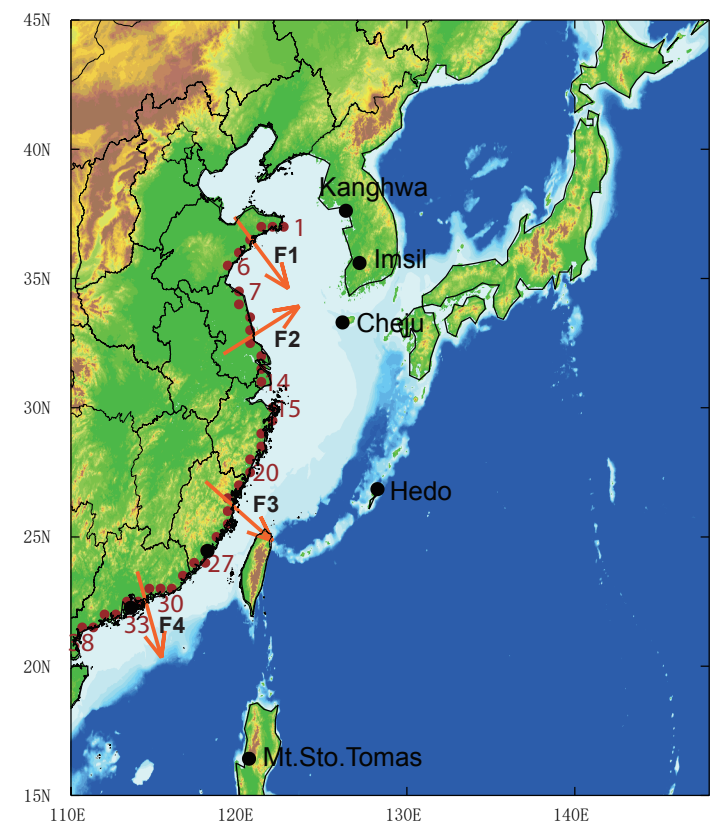

Figure 5. Map of the focused domain. The black dots are the locations of nine EANET sites that used for model evaluation of nitrogen deposition near the coast (Fig. 6): Mt. Sto. Tomas, Hedo, Cheju, Imsil, Kanghwa, Xiamen (Hongwen and Xiaoping sites), and Zhuhai (Xiang Zhou and Zhuxiandong sites). The red dots represent the grid cells covering the coastline of mainland China that are used for determining the outflow fluxes as indicated by the orange arrows.

July. At middle latitudes $\left(>30^{\circ} \mathrm{N}\right)$ along the eastern China coast, nitrogen deposition peaks in July with the highest values greater than $2 \mathrm{~kg} \mathrm{Nha}^{-1}$ month $^{-1}$ along the coastlines. In all seasons, deposition decreases rapidly downwind of the continental sources. Jung et al. (2011), using aerosol and rain samples, estimated total nitrogen deposition fluxes of $32-64 \mu \mathrm{mol} \mathrm{m}{ }^{-2} \mathrm{~d}^{-1}\left(1.6-3.3 \mathrm{~kg} \mathrm{~N} \mathrm{ha}^{-1} \mathrm{a}^{-1}\right)$ in the central Pacific Ocean with $66-99 \%$ via wet deposition. Our model shows similar results $\left(0.8-4 \mathrm{~kg} \mathrm{~N} \mathrm{ha}^{-1} \mathrm{a}^{-1}\right)$.

We selected two regions as shown in Fig. 7 representing the Yellow Sea and the South China Sea. Table 3 summarizes the monthly and annual nitrogen deposition fluxes over the two regions for 2008-2010. Nitrogen deposition averages $11.9 \mathrm{~kg} \mathrm{Nha}^{-1} \mathrm{a}^{-1}$ over the Yellow Sea $\left(5.0 \mathrm{~kg} \mathrm{Nha}^{-1} \mathrm{a}^{-1}\right.$ as reduced nitrogen $\mathrm{NH}_{x}$ and $6.9 \mathrm{~kg} \mathrm{Nha}^{-1} \mathrm{a}^{-1}$ as oxidized nitrogen $\mathrm{NO}_{y}$ ). Seasonal variation of the deposition to the Yellow Sea is weak with fluxes in October and January about $10 \%$ higher than in April and July. Nitrogen deposition to the South China Sea averages $5.6 \mathrm{~kg} \mathrm{Nha}^{-1} \mathrm{a}^{-1}$ with deposition in January nearly a factor of 3 higher than deposition in July. This reflects seasonal variations in both meteorology and nitrogen emissions as will be discussed below.

Wet deposition accounts for $67 \%$ of the total nitrogen deposition to the Yellow Sea ( $82 \%$ for $\mathrm{NH}_{x}$ and $57 \%$ for $\mathrm{NO}_{y}$ ) and the South China Sea ( $84 \%$ for $\mathrm{NH}_{x}$ and $55 \%$ for $\mathrm{NO}_{y}$ ).
The ratio of wet vs. dry deposition over the ocean is generally higher than that over the land, because of slow dry deposition velocities (Table 1) and less nitrogen exported near the surface, particularly for reduced nitrogen. Simulated nitrogen deposition fluxes are in the range of $20-55 \mathrm{~kg} \mathrm{~N} \mathrm{ha}^{-1} \mathrm{a}^{-1}$ in the eastern China, with wet deposition accounting for $65 \%$ of the $\mathrm{NH}_{x}$ deposition and $54 \%$ of the $\mathrm{NO}_{y}$ deposition (Figure not shown).

\subsection{Contribution from the oceanic emissions}

It is important to separate the contributions of ocean vs. land emissions to the nitrogen deposition over the northwestern Pacific. Sources of fixed nitrogen from the ocean include both anthropogenic ship $\mathrm{NO}_{x}$ emissions and natural oceanic $\mathrm{NH}_{3}$ emissions. Those emissions are small compared with land sources, but their contributions to the nitrogen deposition over the open ocean cannot be neglected due to the short lifetimes of nitrogen species. We have conducted two sensitivity simulations respectively with ship $\mathrm{NO}_{x}$ emissions or oceanic $\mathrm{NH}_{3}$ emissions shut off. The differences in the standard simulation represent contributions of each source to the nitrogen deposition.

We separate in Fig. 8 the annual contributions of nitrogen sources over land, ship $\mathrm{NO}_{x}$ emissions, and oceanic $\mathrm{NH}_{3}$ emissions to total nitrogen deposition over the northwestern Pacific. We can see nitrogen deposition to the marginal seas of the northwestern Pacific is dominated by transport of nitrogen sources over the Asian continent. Ship $\mathrm{NO}_{x}$ and oceanic $\mathrm{NH}_{3}$ emissions contribute little nitrogen deposition (together less than 1\%) to the Yellow Sea, and about $7 \%$ over the South China Sea. Further to the equatorial Pacific Ocean ship $\mathrm{NO}_{x}$ emissions contribute $10-25 \%$ of the total nitrogen deposition along the ship tracks, and oceanic $\mathrm{NH}_{3}$ emissions account for $15-40 \%$ of the total nitrogen deposition annually.

\subsection{Outflow from mainland China}

We have demonstrated above that nitrogen deposition to the marginal seas of the northwestern Pacific, such as the Yellow Sea and the South China Sea, mainly originates from nitrogen sources over the land. We now focus on the outflow fluxes from mainland China where the largest nitrogen emissions are located. Figure 9 shows the outflow fluxes of fixed nitrogen transported across the coastline of mainland China (as defined by the grid cells in Fig. 5) in different seasons. Fluxes of $\mathrm{NH}_{3}, \mathrm{NH}_{4}^{+}, \mathrm{HNO}_{3}$, isoprene nitrates, and $\mathrm{NO}_{3}^{-}$are included. Other fixed nitrogen species such as PAN, although important in outflow fluxes, account for less than $1 \%$ of the nitrogen deposition to the northwestern Pacific.

We can see that the spatial and seasonal variations of atmospheric nitrogen deposition over the marginal seas of the northwestern Pacific, as shown in Fig. 7, can be mainly explained by variations of outflow fluxes from China. Nitro- 
(a)
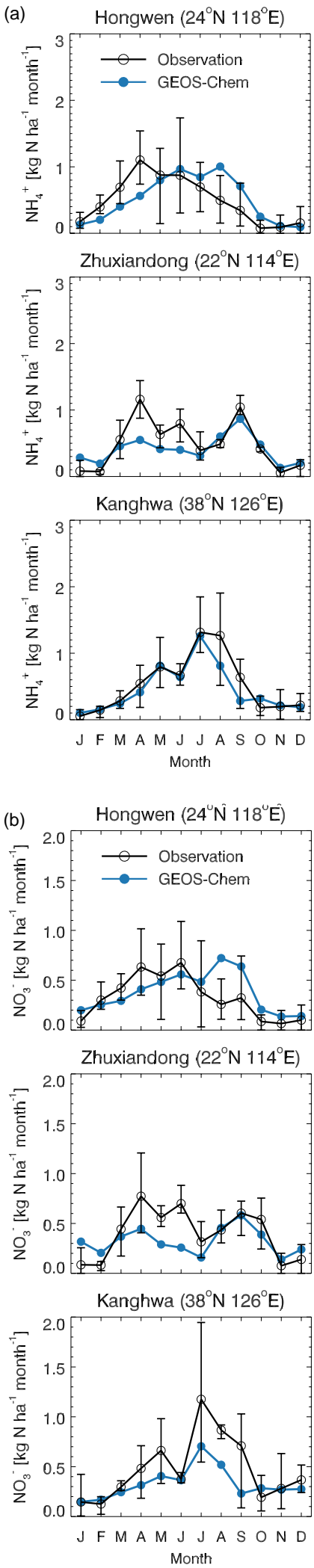
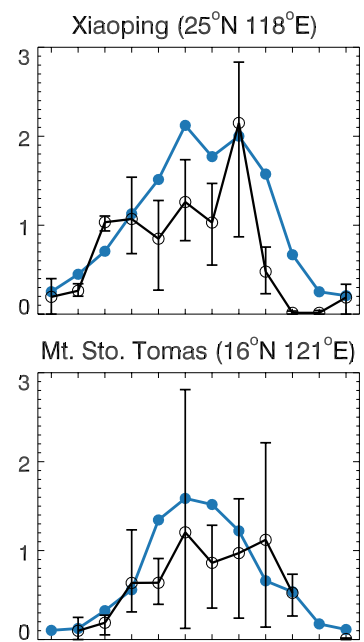

Imsil $\left(36^{\circ} \mathrm{N} 127^{\circ} \mathrm{E}\right)$
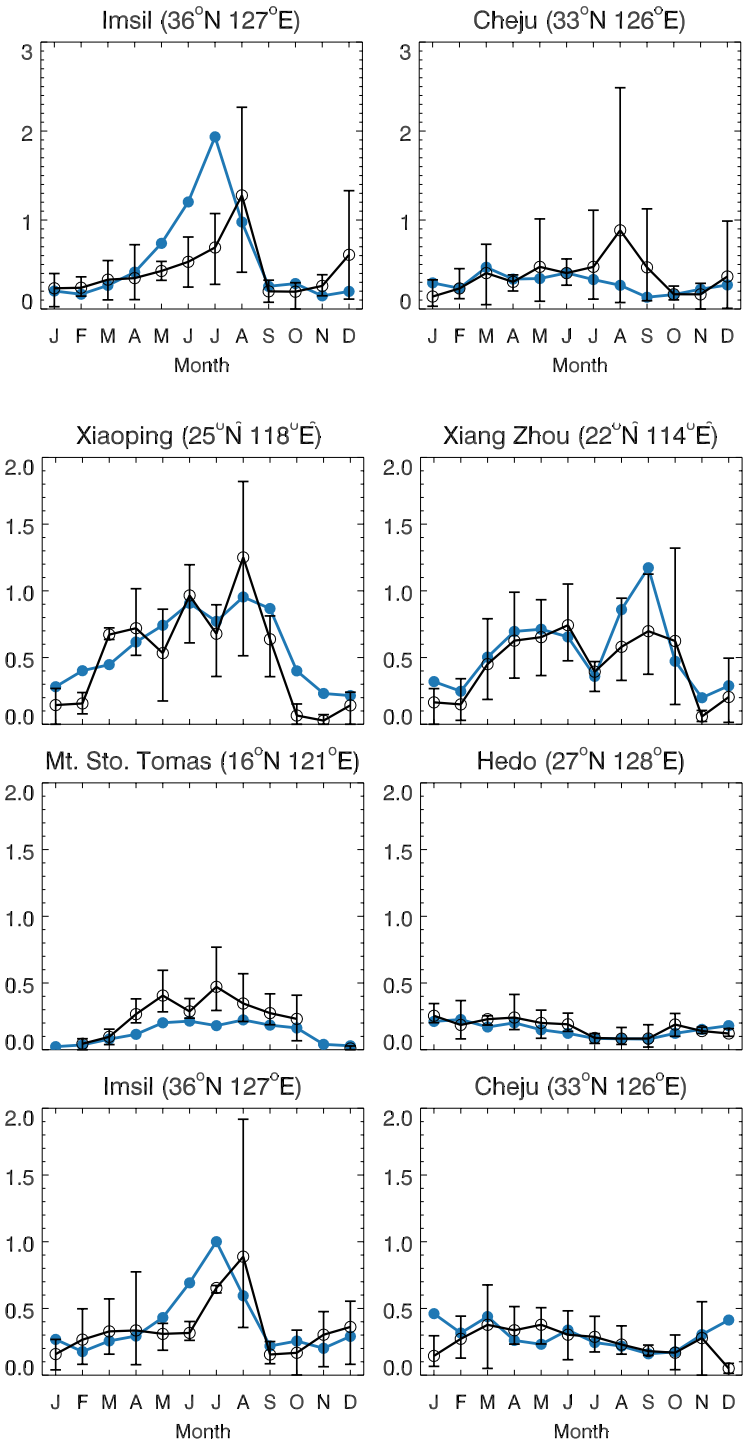

Figure 6. Monthly averaged ammonium (a) and nitrate (b) wet deposition fluxes at nine EANET coastal sites (Fig. 5). The black lines are 3-year averages (2008-2010) of observations, and the blue lines are the corresponding model results. The vertical black lines represent the range of observed values for 2008-2010. 


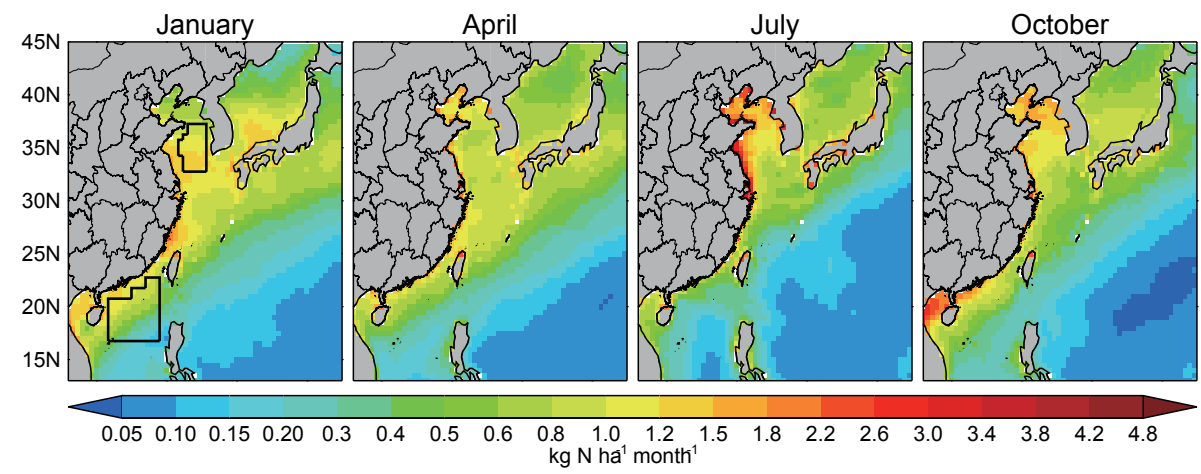

Figure 7. GEOS-Chem simulated monthly nitrogen deposition fluxes to the northwestern Pacific in January, April, July and October 20082010. The black boxes in the left panel represent areas of the Yellow Sea and the South China Sea used in the adjoint analyses.

Table 3. Monthly and annual nitrogen deposition fluxes to the Yellow Sea and the South China Sea for 2008-2010*.

\begin{tabular}{|c|c|c|c|c|c|c|}
\hline & & \multicolumn{2}{|c|}{ Wet deposition } & \multicolumn{2}{|c|}{ Dry deposition } & \multirow[t]{2}{*}{ Total } \\
\hline & & $\mathrm{NH}_{4}^{+}$ & $\mathrm{NO}_{3}^{-}$ & $\mathrm{NH}_{x}$ & $\mathrm{NO}_{y}$ & \\
\hline \multirow{5}{*}{$\begin{array}{c}\text { The Yellow } \\
\text { Sea }\end{array}$} & January & $0.24(0.16-0.27)$ & $0.38(0.25-0.47)$ & $0.05(0.05-0.06)$ & $0.45(0.45-0.45)$ & $1.12(0.92-1.25)$ \\
\hline & April & $0.35(0.21-0.46)$ & $0.27(0.18-0.37)$ & $0.10(0.07-0.12)$ & $0.14(0.13-0.15)$ & $0.85(0.63-1.08)$ \\
\hline & July & $0.48(0.40-0.60)$ & $0.36(0.30-0.43)$ & $0.08(0.06-0.11)$ & $0.13(0.11-0.15)$ & $1.04(0.89-1.28)$ \\
\hline & October & $0.34(0.20-0.53)$ & $0.32(0.21-0.46)$ & $0.12(0.07-0.17)$ & $0.29(0.22-0.38)$ & $1.07(0.71-1.54)$ \\
\hline & Annual & $4.1(3.8-4.2)$ & $3.9(3.9-3.9)$ & $0.9(0.8-1.0)$ & $3.0(2.8-3.1)$ & $11.9(11.3-12.3)$ \\
\hline \multirow{5}{*}{$\begin{array}{l}\text { The South } \\
\text { China Sea }\end{array}$} & January & $0.18(0.13-0.24)$ & $0.17(0.12-0.21)$ & $0.03(0.02-0.04)$ & $0.23(0.15-0.34)$ & $0.62(0.43-0.83)$ \\
\hline & April & $0.20(0.14-0.26)$ & $0.12(0.08-0.16)$ & $0.04(0.04-0.05)$ & $0.08(0.07-0.09)$ & $0.43(0.34-0.56)$ \\
\hline & July & $0.10(0.04-0.14)$ & $0.09(0.05-0.11)$ & $0.02(0.01-0.02)$ & $0.02(0.01-0.02)$ & $0.23(0.11-0.29)$ \\
\hline & October & $0.20(0.16-0.24)$ & $0.16(0.13-0.22)$ & $0.05(0.04-0.07)$ & $0.13(0.10-0.18)$ & $0.54(0.42-0.63)$ \\
\hline & Annual & $2.1(1.8-2.3)$ & $1.7(1.5-1.8)$ & $0.4(0.4-0.5)$ & $1.4(1.2-1.5)$ & $5.6(4.8-6.1)$ \\
\hline
\end{tabular}

* Numbers are 3-year (2008-2010) averages and ranges (in parentheses) in units of $\mathrm{kg} \mathrm{Nha}^{-1}$ month$^{-1}$ for the monthly values and $\mathrm{kg} \mathrm{Nha}^{-1} \mathrm{a}^{-1}$ for the annual totals.

gen outflow fluxes across the eastern coastline (cell 1-14 in Fig. 5) to the Yellow Sea show strong transport from Jiangsu Province (cell 7-14 in Fig. 5) below $800 \mathrm{hPa}$ corresponding to the maximum nitrogen deposition near the east coast of China in July. Fluxes in April and October are strong in the free troposphere, where the lifetimes of nitrogen species are longer than in the boundary layer leading to deposition further to the open ocean of the Yellow Sea. Over the southern coastline (cell 20-38 in Fig. 5) to the South China Sea, nitrogen fluxes are the largest within the boundary layer in January and October. The fluxes turn to inflow in April and July, minimizing deposition to the South China Sea during these months.

The seasonal variation of pollution transport over East Asia is largely controlled by the East Asian monsoon system (Liu et al., 2003; Liang et al., 2004; Zhang et al., 2010). We show in Fig. 10 the monthly mean wind fields averaged in the boundary layer (generally below $950 \mathrm{hPa}$ ) and in the free troposphere at $700 \mathrm{hPa}$ plotted over the monthly emissions of fixed nitrogen. In January the northwesterly monsoon prevails at middle latitudes $\left(>30^{\circ}\right)$ in the boundary layer and gradually turns to the northeasterly at lower latitudes $\left(<30^{\circ}\right)$. Asian pollution is generally trapped in the boundary layer by the large-scale subsidence over the continent and transported southward as shown in Fig. 9. In July, the summer southerly monsoon winds bring clean ocean air to southern China, but at latitudes north of $30^{\circ} \mathrm{N}$ the southwesterly winds combined with the high nitrogen emissions over eastern China lead to large fluxes to the Yellow Sea. Spring and fall represent the transitional periods, and frequent cold fronts are the primary driver lifting anthropogenic pollution to the free troposphere followed by westerly transport (Liu et al., 2003; Liang et al., 2004).

Thus, the strong seasonal variation in nitrogen deposition to the South China Sea is mainly attributed to the monsoonal Asian outflow. Over the Yellow Sea, we find the weaker winds in July can be compensated by higher nitrogen emissions over the land, leading to the weak seasonality of nitrogen deposition. We find in a sensitivity simulation without seasonal variations of Asian $\mathrm{NH}_{3}$ emissions that nitrogen deposition to the Yellow Sea would have been $64 \%$ higher in January than July. 

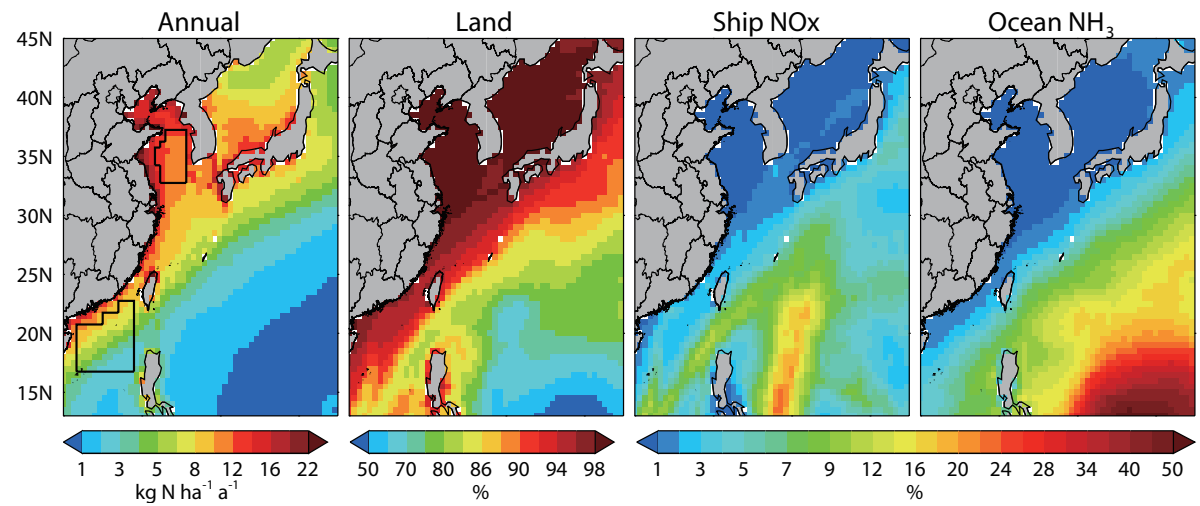

Figure 8. Annual total nitrogen deposition fluxes to the northwestern Pacific averaged in 2008-2010 (first panel), and annual percentage contributions from nitrogen sources over land, ship $\mathrm{NO}_{x}$ emissions, and oceanic $\mathrm{NH}_{3}$ emissions.
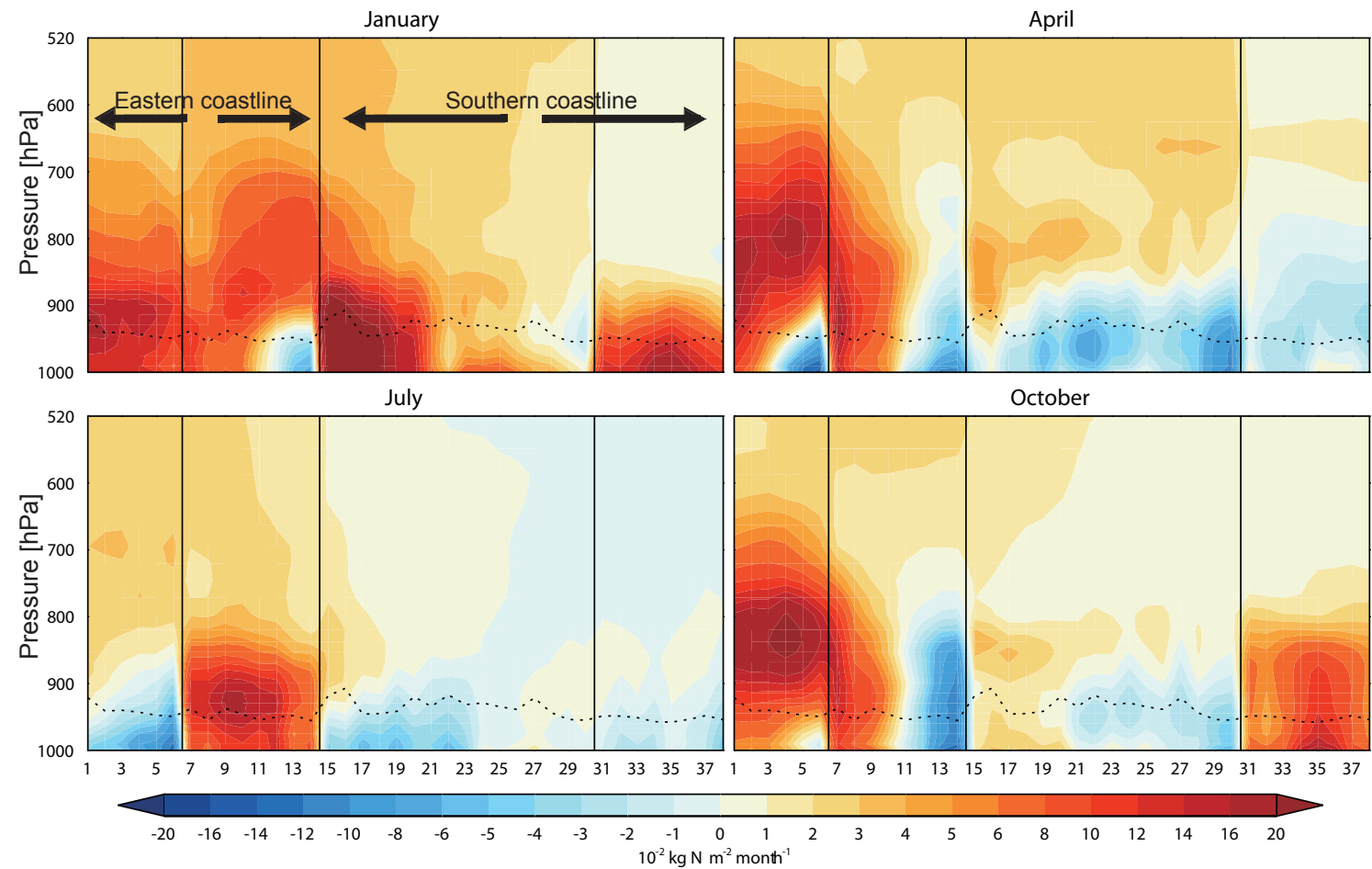

Figure 9. Vertical profile of fixed nitrogen (totals of $\mathrm{NH}_{3}, \mathrm{NH}_{4}^{+}, \mathrm{HNO}_{3}$, isoprene nitrates, and $\mathrm{NO}_{3}^{-}$) transported from the mainland of China to the ocean. The numbers in the $x$ coordinate corresponds to the grid cell number in Fig. 5. Positive values represent transport outside mainland China, while negative values represent the opposite transport. The dotted lines represent the model boundary layer height. Three back lines divide the each panel in four parts. From left to right, we calculated transportation of nitrogen in each part in the direction of arrow F1-F4.

\section{Source attribution using the adjoint method}

The adjoint model allows us to further quantify the sources contributing to atmospheric nitrogen deposition over the receptors at the model underlying grid scale. Here we calculate the sensitivities of nitrogen deposition (reduced and oxidized nitrogen, wet and dry) over the Yellow Sea and the South China Sea to grid-resolved $\mathrm{NH}_{3}$ and $\mathrm{NO}_{x}$ emissions for January, April, July, and October 2009. For each month, we calculate sensitivity of the monthly mean nitrogen deposition to emissions in that month and a week in the preceding month (accounting for the lifetimes of nitrogen species). We separate the sensitivities to different source types (e.g., fertilizer and livestock for $\mathrm{NH}_{3}$, and industry and power plants for $\mathrm{NO}_{x}$ ) based on their relative contributions to the total anthropogenic emissions.

The top panels of Fig. 11 show the adjoint sensitivities for the monthly total nitrogen deposition to the Yellow Sea. The 


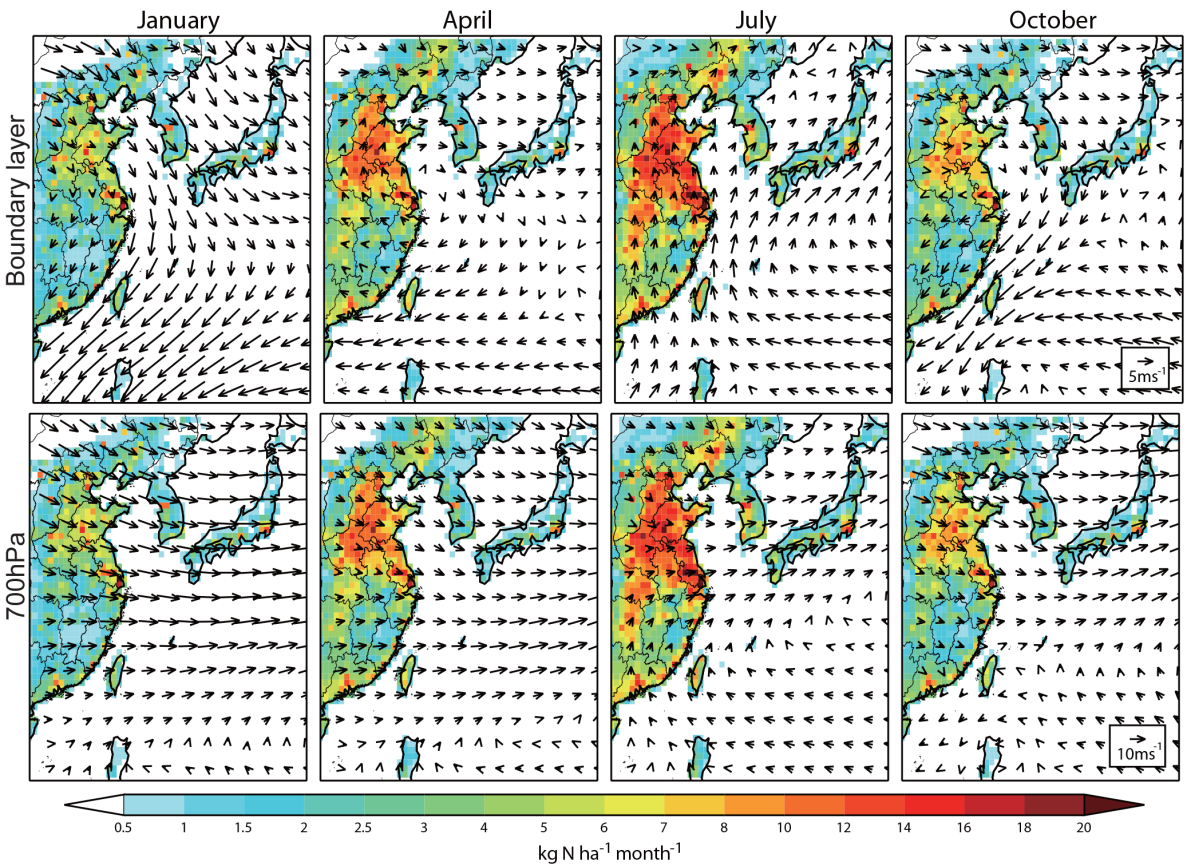

Figure 10. Monthly mean wind fields from the GEOS-5 assimilated meteorological data over-plotted on the monthly emissions of fixed nitrogen $\left(\mathrm{NH}_{3}+\mathrm{NO}_{x}\right)$. The top panels are wind fields in the boundary layer $(1000-950 \mathrm{hPa})$ and the bottom panels show the wind fields in the free troposphere $(700 \mathrm{hPa})$.

magnitude of adjoint sensitivity reflects deposition amount contributed by the nitrogen emissions in each grid cell. The sum of sensitivities integrated geographically matches the monthly deposition flux to the Yellow Sea within 5\%. From winter to summer the source regions move southward from North China and northeast China to East China and central China, consistent with the seasonal variation of the monsoonal flow. Nitrogen sources over China are the main contributor to the nitrogen deposition to the Yellow Sea (93\% in January, $88 \%$ in July, and $92 \%$ annually). Sources over the Korean peninsula contribute $7 \%$ of annual nitrogen deposition to the Yellow Sea.

The bottoms panels of Fig. 11 separate the sensitivities of nitrogen deposition components (reduced and oxidized nitrogen, wet and dry) to emissions from different source types. The total sensitivity of each deposition component also approximately matches the simulated deposition flux (Table 3), with small discrepancies of $0.01-0.06 \mathrm{~kg} \mathrm{Nha}^{-1}$ month $^{-1}$ that can be attributed to nonlinearity between nitrogen deposition and emissions (including nitrogen, $\mathrm{SO}_{2}$, and $\mathrm{VOC}$ emissions) as discussed in Paulot et al. (2013). Figure 11 shows that $\mathrm{NO}_{x}$ emissions from power plants $(37 \%)$, followed by emissions from transport $(26 \%)$ and industry $(22 \%)$ contribute most of the nitrogen deposition in January. In other months, $\mathrm{NH}_{3}$ emissions from fertilizer use (25$32 \%$ ) are the largest source of nitrogen deposition to the Yellow Sea. Annually the major sources contributing to nitrogen deposition to the Yellow Sea are fertilizer use $(24 \%)$, power plants (22\%), and transportation (18\%).

Figure 12 shows source attribution of atmospheric nitrogen deposition to the South China Sea. Unlike that to the Yellow Sea, nitrogen deposition to the South China Sea shows a distinct winter peak as reflected by the largest source contributing areas in January spreading over the Asian continent. Kim et al. (2014) using back trajectories suggested transport of nitrogen from the east coasts of China and Indonesia to the South China Sea. Here we estimate that nitrogen deposition to the South China Sea is mainly from mainland China and Taiwan, contributing 66 and $20 \%$ of the annual total nitrogen deposition. The remaining $14 \%$ results from sources over the southeast Asian countries as well as oceanic $\mathrm{NH}_{3}$ emissions.

For the sectorial contributions, nitrogen sources from power plants, transport, industry, and fertilizer use show comparable contribution to nitrogen deposition over the South China Sea in January (16-21\%) and October (14$23 \%$ ). But in April and July, fertilizer use and natural emissions become most significant. In April, natural emissions account for $17 \%$ of the nitrogen deposition to the South China Sea mainly via wet deposition, including $7 \%$ from the oceanic $\mathrm{NH}_{3}$ emissions, $4 \%$ from lightning, and $6 \%$ from biomass burning emissions over southeast Asia.

One interesting feature we can see from Figs. 11 and 12 is that anthropogenic $\mathrm{NO}_{y}$ dry deposition exhibits a different response to increasing $\mathrm{NH}_{3}$ emissions over the Yellow Sea (negative) and the South China Sea (near zero). It indi- 

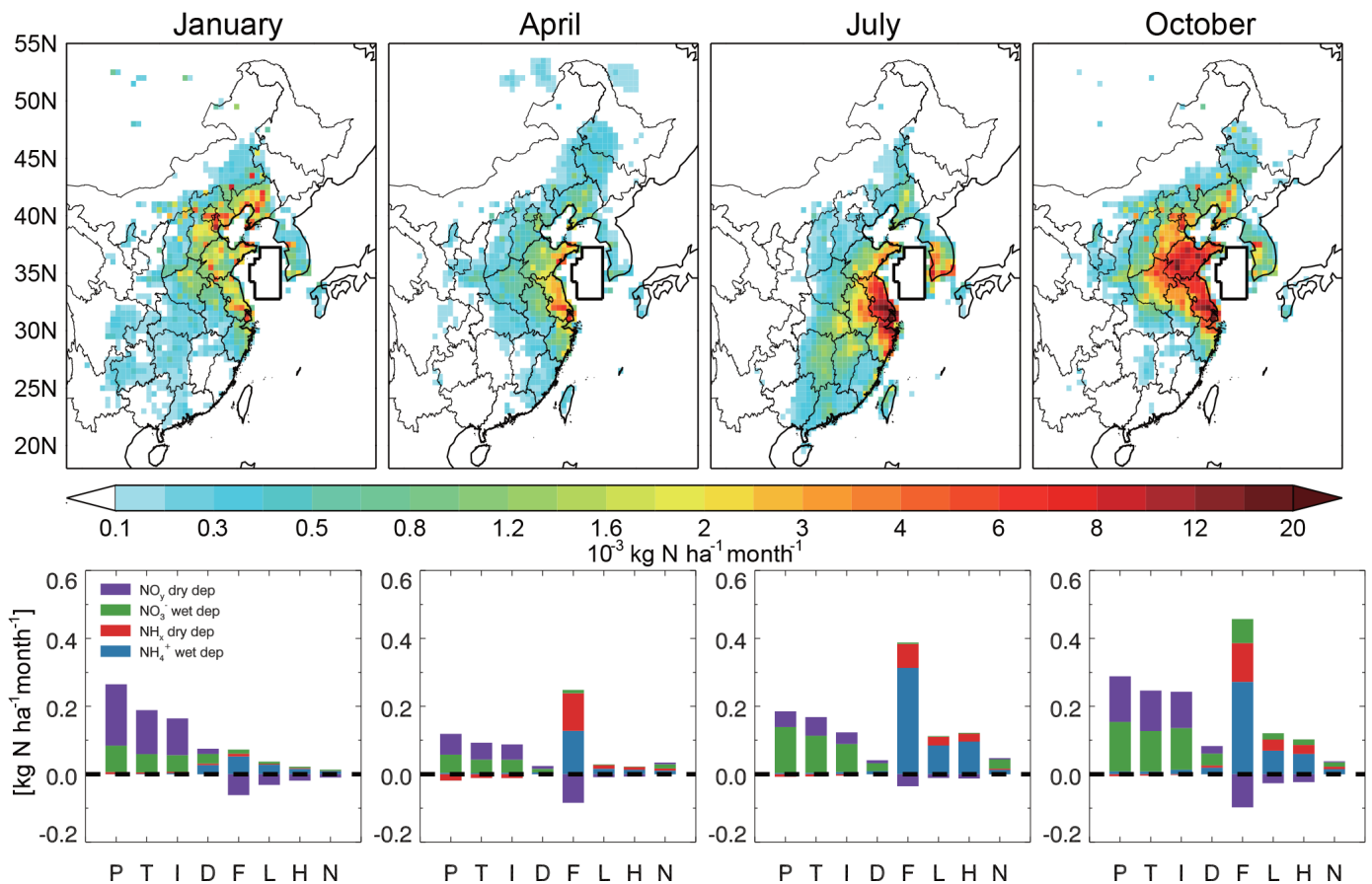

Figure 11. (Top panels) sensitivity of monthly total nitrogen deposition over the Yellow Sea to emissions in each grid box, and (bottom panels) sensitivity of nitrogen deposition over the Yellow sea (domain defined by the black lines) to each emission sector. In the $x$ axis, label $\mathrm{P}$ denotes power plant, T: transport, I: industry, D: domestic, F: fertilizer use, L: livestock, H: human waste, and N: natural emissions.
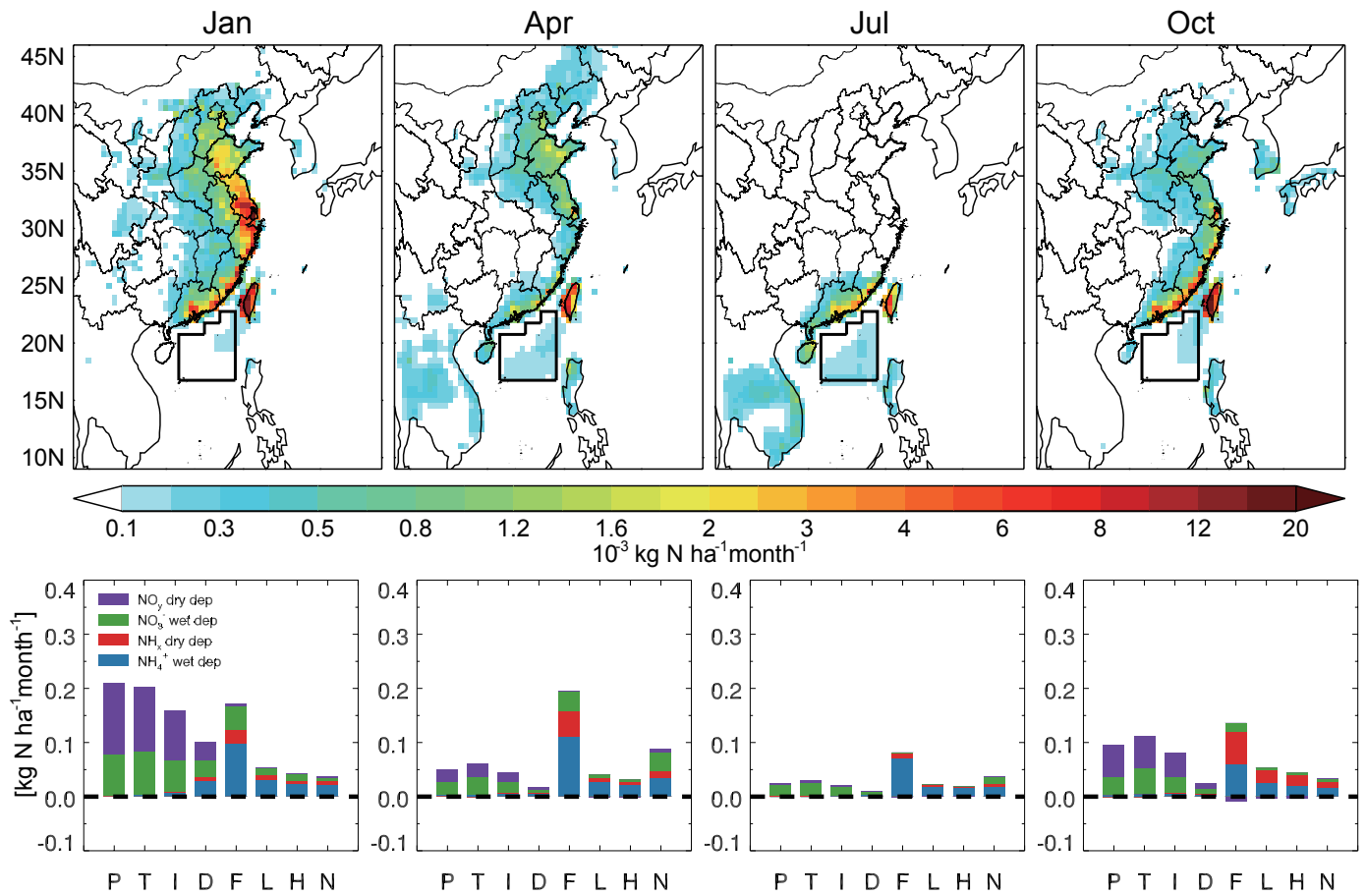

Figure 12. Same as Fig. 11 but for the South China Sea. 


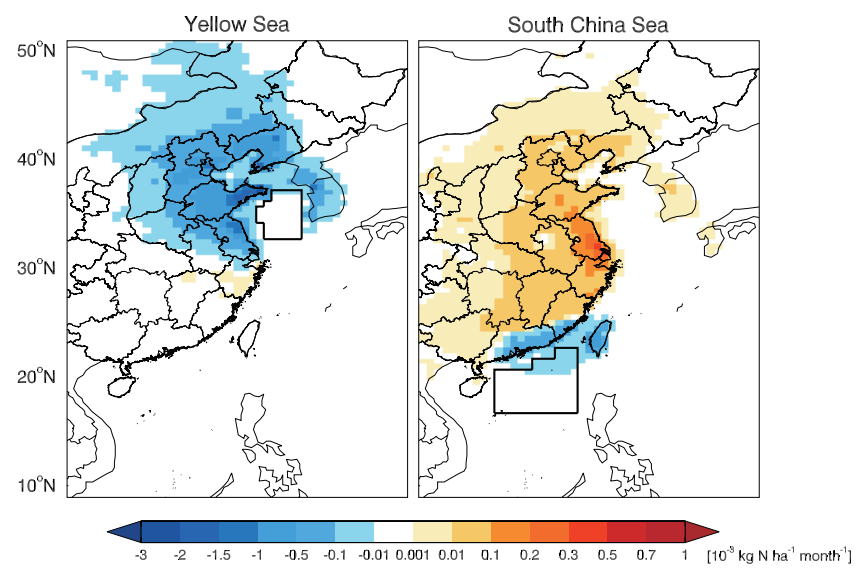

Figure 13. Sensitivity of $\mathrm{NO}_{y}$ dry deposition over the Yellow Sea (left) and over the South China Sea (right) to $\mathrm{NH}_{3}$ emissions in each model grid box for January 2009.

cates that reducing $\mathrm{NH}_{3}$ emissions would even enhance dry deposition of $\mathrm{NO}_{y}$ to the Yellow Sea. In Fig. 13 we show the sensitivity of $\mathrm{NO}_{y}$ dry deposition to $\mathrm{NH}_{3}$ emissions for deposition to the Yellow sea and to the South China Sea in January 2009. The values are generally negative for the Yellow Sea, and positive for the South China Sea except for the areas near the coast.

This can be explained by the conversion of $\mathrm{HNO}_{3}$ to aerosol $\mathrm{NO}_{3}^{-}$and their different dry deposition velocities. Dry deposition velocities for aerosol nitrate is much slower than $\mathrm{HNO}_{3}$ gas (Table 1). $\mathrm{NH}_{3}$ emissions would lead to formation of aerosol $\mathrm{NO}_{3}^{-}$from $\mathrm{HNO}_{3}$, increasing the lifetime of $\mathrm{NO}_{y}$ and allowing them transport to a longer distance. It would thus decrease the dry deposition of $\mathrm{NO}_{y}$ (mainly via reduction of $\mathrm{HNO}_{3}$ ) near the source region (e.g., the Yellow Sea), and enhance its dry deposition further downwind (e.g., the South China Sea). The same response applies to $\mathrm{NH}_{x}$ dry deposition and $\mathrm{NO}_{x}$ emissions (the April panel of Fig. 11), but it is much weaker because $\mathrm{NH}_{x}$ dry deposition fluxes to the ocean are small and mainly from dry deposition of aerosol $\mathrm{NH}_{4}^{+}$. This can have important implications on the effectiveness of the emission control strategy for reducing nitrogen deposition to the Yellow Sea. As shown in Fig. 11, $\mathrm{NH}_{3}$ emissions from fertilizer use are identified as the largest contributor to nitrogen deposition to the Yellow Sea except in winter. However, we estimate annually $28 \%$ (negative sensitivity of $\mathrm{NO}_{y}$ dry deposition vs. sensitivity of $\mathrm{NH}_{x}$ total deposition to $\mathrm{NH}_{3}$ emissions, averaged over the 4 months in Fig. 11) of the expected benefits of reduction of nitrogen deposition to the Yellow Sea via controlling $\mathrm{NH}_{3}$ would be offset by an increase in $\mathrm{NO}_{y}$ dry deposition.

\section{Conclusions}

Increasing atmospheric nitrogen deposition to the northwestern Pacific has likely been altering the marine environment. The purpose of this study is to quantify the sources, processes, and seasonal variation of atmospheric nitrogen deposition to the northwestern Pacific. We have used a nested-grid version of the GEOS-Chem global chemistry model and its adjoint model to address the issue. The model has a horizontal resolution of $1 / 2^{\circ}$ latitude $\times 2 / 3^{\circ}$ longitude over East Asia and its adjacent oceans $\left(70-150^{\circ} \mathrm{E}, 11^{\circ} \mathrm{S}-55^{\circ} \mathrm{N}\right)$, and $4^{\circ} \times 5^{\circ}$ over the rest of the world. It includes a detailed tropospheric chemistry to simulate the sources, transformation, and deposition of fixed nitrogen $\left(\mathrm{NH}_{x}\right.$ and $\left.\mathrm{NO}_{y}\right)$ in the atmosphere.

The model uses the anthropogenic emissions of fixed nitrogen (via $\mathrm{NH}_{3}$ and $\mathrm{NO}_{x}$ ) from the REAS-v2 emission inventory for Asia (Kurokawa et al., 2013). The original $\mathrm{NH}_{3}$ emissions had no seasonal variation, inconsistent with recent Asian $\mathrm{NH}_{3}$ emission estimates. We calculate the seasonal variations for $\mathrm{NH}_{3}$ emissions from fertilizer use based on soil properties, meteorology, and the timing of fertilizer application (Skjøth et al., 2011; Paulot et al., 2014), and for $\mathrm{NH}_{3}$ from livestock and human waste using surface temperature (Aneja et al., 2000). The resulting Asian $\mathrm{NH}_{3}$ emissions are the highest in May-August, with emissions in summer a factor of 3 higher than winter. Total Asian $\mathrm{NH}_{3}$ and $\mathrm{NO}_{x}$ emissions are 28.6 and $16.2 \mathrm{Tg} \mathrm{N} \mathrm{a}^{-1}$, respectively. China has the largest nitrogen sources with $12.8 \mathrm{Tg} \mathrm{Na}^{-1}$ as $\mathrm{NH}_{3}$ and $7.9 \mathrm{Tg} \mathrm{Na}{ }^{-1}$ as $\mathrm{NO}_{x}$. Both $\mathrm{NH}_{3}$ and $\mathrm{NO}_{x}$ emissions are dominated by anthropogenic sources. Natural sources account for $7 \%$ for $\mathrm{NH}_{3}$, and $16 \%$ for $\mathrm{NO}_{x}$.

We evaluate the model simulation of $\mathrm{NH}_{3}$ and $\mathrm{NO}_{2}$ tropospheric columns with satellite observations from TES and OMI over Asia. The model generally captures the observed distribution of $\mathrm{NH}_{3}$ and $\mathrm{NO}_{2}$ tropospheric columns with only small negative biases for both species $\left(-3 \%\right.$ for $\mathrm{NH}_{3}$ over China and up to $-15 \%$ for $\mathrm{NO}_{2}$ over the North China), providing support to the model emissions. The model further closely reproduces the magnitudes and variability of ammonium and nitrate wet deposition fluxes at the EANET sites and additional monitoring sites over North China. Wet deposition fluxes measured over the continental sites show strong seasonality with summer maximum and winter minimum, while for the island sites in the open ocean, deposition fluxes are much smaller with weak seasonal variations.

We analyze a 3-year (2008-2010) model simulation of atmospheric nitrogen deposition to the northwestern Pacific, particularly over the marginal seas such as the Yellow Sea and the South China Sea. Atmospheric nitrogen deposition reaches as high as $20-55 \mathrm{~kg} \mathrm{Nha}^{-1} \mathrm{a}^{-1}$ in the eastern China, and decreases rapidly downwind of the Asian continent (0.8 $20 \mathrm{~kg} \mathrm{Nha}^{-1} \mathrm{a}^{-1}$ over the northwestern Pacific). Nitrogen deposition averages $11.9 \mathrm{~kg} \mathrm{Nha}^{-1} \mathrm{a}^{-1}$ over the Yellow Sea (5.0 $\mathrm{kg} \mathrm{Nha}^{-1} \mathrm{a}^{-1}$ as $\mathrm{NH}_{x}$ and $6.9 \mathrm{~kg} \mathrm{Nha}^{-1} \mathrm{a}^{-1}$ as $\mathrm{NO}_{y}$ ), 
and $5.6 \mathrm{~kg} \mathrm{Nha}^{-1} \mathrm{a}^{-1}$ to the South China Sea $\left(2.5\right.$ as $\mathrm{NH}_{x}$ and 3.1 as $\mathrm{NO}_{y}$ ). Although Asian $\mathrm{NH}_{3}$ emissions are much higher than $\mathrm{NO}_{x}$ emissions, less $\mathrm{NH}_{x}$ is exported and deposited over the open ocean due to its shorter lifetime. We find contributions of nitrogen sources over the ocean, including ship $\mathrm{NO}_{x}$ emissions and oceanic $\mathrm{NH}_{3}$ emissions, are negligible for nitrogen deposition to the Yellow Sea, and about $7 \%$ over the South China Sea. Further downwind in the ocean ship $\mathrm{NO}_{x}$ emissions contribute $10-25 \%$ of total nitrogen deposition along the ship tracks, and oceanic $\mathrm{NH}_{3}$ emissions are responsible for $15-40 \%$ of the nitrogen deposition.

Seasonal variations in nitrogen deposition to the northwestern Pacific are generally determined by variations in meteorology and nitrogen emissions. Nitrogen deposition to the South China Sea showed strong seasonal variation, with deposition in January $\left(0.62 \mathrm{~kg} \mathrm{Nha}^{-1}\right.$ month $\left.^{-1}\right)$ nearly a factor of 3 higher than deposition in July $\left(0.23 \mathrm{~kg} \mathrm{Nha}^{-1}\right.$ month $\left.^{-1}\right)$. This is consistent with the nitrogen outflow fluxes from Asia (mainly mainland China), which are controlled by the East Asian monsoon system as discussed in previous studies (Liu et al., 2003; Zhang et al., 2010). In winter the northerly monsoon favors transport of Asian pollution to the open ocean in the boundary layer, while the summer southerly monsoon winds bring clean ocean air to southern China. Nitrogen deposition to the Yellow Sea has weak seasonality (0.85$1.12 \mathrm{~kg} \mathrm{Nha}^{-1}$ month $^{-1}$ ). We find the weaker winds in summer over the Yellow Sea suppress dry deposition of nitrogen, but are compensated by higher nitrogen emissions in summer.

We have further applied the adjoint of GEOS-Chem to estimate the contributions of nitrogen sources from different sectors and at the model underlying resolution to nitrogen deposition over the Yellow Sea and the South China Sea. This detailed source information can be crucial to design an effective strategy for reducing nitrogen deposition to these areas. Nitrogen deposition to the Yellow Sea mainly originates from nitrogen sources over China ( $92 \%$ contribution) and the Korean peninsula ( $7 \%$ ) categorized by regions, and is contributed from fertilizer use (24\%), power plants (22\%), and transportation (18\%) categorized by emission sectors. For deposition to the South China Sea, nitrogen sources over mainland China and Taiwan contribute 66 and $20 \%$ of the annual total deposition, respectively, with the remaining $14 \%$ coming from sources over the southeast Asian countries as well as oceanic $\mathrm{NH}_{3}$ emissions. Natural sources are particularly important in April, accounting for $17 \%$ of the nitrogen deposition to the South China Sea (7\% from the oceanic $\mathrm{NH}_{3}$ emissions, $4 \%$ from lightning, and $6 \%$ from biomass burning emissions over southeast Asia).

The adjoint analyses also indicate that dry deposition of oxidized nitrogen to the Yellow Sea shows negative sensitivity to Asian $\mathrm{NH}_{3}$ emissions, i.e., reducing Asian $\mathrm{NH}_{3}$ emissions would increase the $\mathrm{NO}_{y}$ dry deposition to the Yel- low Sea. This response mainly reflects conversion of gaseous $\mathrm{NH}_{3}$ and $\mathrm{HNO}_{3}$ to ammonium nitrate aerosol and their different deposition efficiencies. Annually, $28 \%$ of the reduction of nitrogen deposition to the Yellow Sea via reducing $\mathrm{NH}_{3}$ emissions would be offset by increases in $\mathrm{NO}_{y}$ dry deposition, placing a limitation on the effectiveness of $\mathrm{NH}_{3}$ emission controls for mitigating nitrogen deposition over the Yellow Sea.

While this study provides a pilot investigation of the sources and processes controlling atmospheric nitrogen deposition to the northwestern Pacific, some uncertainties still need to be considered. A main uncertainty is associated with the lack of in situ measurements to evaluate the model simulated nitrogen dry deposition fluxes. Uncertainties exist in both model calculated dry deposition velocities over the ocean surface (as discussed in Sect. 2.1) and simulated surface concentrations of nitrogen species. Recent studies have shown that GEOS-Chem overestimates wintertime surface concentrations of nitrate and nitric acid (Heald et al., 2012; Zhang et al., 2012; Wang et al., 2013), which can lead to a model overestimation of $\mathrm{NO}_{y}$ dry deposition flux in winter.

Uncertainties also exist in Asian $\mathrm{NH}_{3}$ emissions; in particular, air-surface bi-directional $\mathrm{NH}_{3}$ fluxes are not considered in the study. Although it has little impact on the oceanic emissions, recent implementations of the bi-directional $\mathrm{NH}_{3}$ flux on fertilizer use showed lower $\mathrm{NH}_{3}$ agricultural emissions over China (Fu et al., 2015; L. Zhu et al., 2015), and thus would lower its transport to the ocean. In addition, any bias in the GEOS-Chem simulation would affect the adjoint sensitivity. Also to ascribe nitrogen deposition to sources from different emission sectors, we rely on the bottom-up sectorial emissions to separate the adjoint sensitivity. Even though the total emissions can be constrained with the satellite measurements, the sectorial information is subject to larger uncertainties (Zhang et al., 2009). We recommend future research to reduce these uncertainties.

Acknowledgements. This work was supported by the National Key Basic Research Program of China (grant 2014CB441303), and by the National Natural Science Foundation of China (grants 41205103, 41475112, and 41405144). FP and DKH acknowledge funding support from the NASA Air Quality Applied Science Team (AQAST). The authors also acknowledge the work of many individuals who have made the measurements of EANET, OMI, and TES.

Edited by: J. Ma 


\section{References}

Amos, H. M., Jacob, D. J., Holmes, C. D., Fisher, J. A., Wang, Q., Yantosca, R. M., Corbitt, E. S., Galarneau, E., Rutter, A. P., Gustin, M. S., Steffen, A., Schauer, J. J., Graydon, J. A., Louis, V. L. St., Talbot, R. W., Edgerton, E. S., Zhang, Y., and Sunderland, E. M.: Gas-particle partitioning of atmospheric $\mathrm{Hg}(\mathrm{II})$ and its effect on global mercury deposition, Atmos. Chem. Phys., 12, 591-603, doi:10.5194/acp-12-591-2012, 2012.

Aneja, V. P., Chauhan, J. P., and Walker, J. T.: Characterization of atmospheric ammonia emissions from swine waste storage and treatment lagoons, J. Geophys. Res.-Atmos., 105, 11535-11545, 2000.

Beer, R.: TES on the Aura mission: scientific objectives, measurements, and analysis overview, IEEE T. Geosci. Remote, 44, 1102-1105, 2006.

Bey, I., Jacob, D. J., Yantosca, R. M., Logan, J. A., Field, B. D., Fiore, A. M., Li, Q. B., Liu, H. G. Y., Mickley, L. J., and Schultz, M. G.: Global modeling of tropospheric chemistry with assimilated meteorology: model description and evaluation, J. Geophys. Res.-Atmos., 106, 23073-23095, 2001.

Boersma, K. F., Jacob, D., Bucsela, E., Perring, A., Dirksen, R., van der A, R., Yantosca, R., Park, R., Wenig, M., Bertram, T., and Cohen, R.: Validation of OMI tropospheric $\mathrm{NO}_{2}$ observations during INTEX-B and application to constrain $\mathrm{NO}_{x}$ emissions over the eastern United States and Mexico, Atmos. Environ., 42, 4480-4497, 2008.

Boersma, K. F., Jacob, D. J., Trainic, M., Rudich, Y., DeSmedt, I., Dirksen, R., and Eskes, H. J.: Validation of urban $\mathrm{NO}_{2}$ concentrations and their diurnal and seasonal variations observed from the SCIAMACHY and OMI sensors using in situ surface measurements in Israeli cities, Atmos. Chem. Phys., 9, 3867-3879, doi:10.5194/acp-9-3867-2009, 2009.

Boersma, K. F., Eskes, H. J., Dirksen, R. J., van der A, R. J., Veefkind, J. P., Stammes, P., Huijnen, V., Kleipool, Q. L., Sneep, M., Claas, J., Leitão, J., Richter, A., Zhou, Y., and Brunner, D.: An improved tropospheric $\mathrm{NO}_{2}$ column retrieval algorithm for the Ozone Monitoring Instrument, Atmos. Meas. Tech., 4, 19051928, doi:10.5194/amt-4-1905-2011, 2011.

Bouwman, A. F., Lee, D. S., Asman, W. A. H., Dentener, F. J., VanderHoek, K. W., and Olivier, J. G. J.: A global high-resolution emission inventory for ammonia, Global Biogeochem. Cy., 11, 561-587, 1997.

Bouwman, A. F., Van Vuuren, D. P., Derwent, R. G., and Posch, M.: A global analysis of acidification and eutrophication of terrestrial ecosystems, Water Air Soil. Poll., 141, 349-382, 2002.

Bowman, W. D., Cleveland, C. C., Halada, L., Hresko, J., and Baron, J. S.: Negative impact of nitrogen deposition on soil buffering capacity, Nat. Geosci., 1, 767-770, 2008.

Capps, S. L., Henze, D. K., Hakami, A., Russell, A. G., and Nenes, A.: ANISORROPIA: the adjoint of the aerosol thermodynamic model ISORROPIA, Atmos. Chem. Phys., 12, 527-543, doi:10.5194/acp-12-527-2012, 2012.

Chen, D., Wang, Y., McElroy, M. B., He, K., Yantosca, R. M., and Le Sager, P.: Regional CO pollution and export in China simulated by the high-resolution nested-grid GEOS-Chem model, Atmos. Chem. Phys., 9, 3825-3839, doi:10.5194/acp-9-3825-2009, 2009.

Dickerson, R., Li, C., Li, Z., Marufu, L., Stehr, J., McClure, B., Krotkov, N., Chen, H., Wang, P., and Xia, X.: Aircraft obser- vations of dust and pollutants over northeast China: insight into the meteorological mechanisms of transport, J. Geophys. Res.Atmos, 112, 1984-2012, 2007.

Dong, W., Xing, J., and Wang, S. X.: Temporal and spatial distribution of anthropogenic ammonia emissions in China: 1994-2006, Environ. Sci., 31, 1457-1463, 2010.

Duce, R. A., Liss, P. S., Merrill, J. T., Atlas, E. L., Buat-Menard, P., Hicks, B. B., Miller, J. M., Prospero, J. M., Arimoto, R., Church, T. M., Ellis, W., Galloway, J. N., Hansen, L., Jickells, T. D., Knap, A. H., Reinhardt, K. H., Schneider, B., Soudine, A., Tokos, J. J., Tsunogai, S., Wollast, R., and Zhou, M.: The atmospheric input of trace species to the world ocean, Global Biogeochem. Cy., 5, 193-259, 1991.

Duce, R. A., LaRoche, J., Altieri, K., Arrigo, K. R., Baker, A. R., Capone, D. G., Cornell, S., Dentener, F., Galloway, J., Ganeshram, R. S., Geider, R. J., Jickells, T., Kuypers, M. M., Langlois, R., Liss, P. S., Liu, S. M., Middelburg, J. J., Moore, C. M., Nickovic, S., Oschlies, A., Pedersen, T., Prospero, J., Schlitzer, R., Seitzinger, S., Sorensen, L. L., Uematsu, M., Ulloa, O., Voss, M., Ward, B., and Zamora, L.: Impacts of atmospheric anthropogenic nitrogen on the open ocean, Science, 320, 893-897, 2008.

Evans, M. J. and Jacob, D. J.: Impact of new laboratory studies of $\mathrm{N}_{2} \mathrm{O}_{5}$ hydrolysis on global model budgets of tropospheric nitrogen oxides, ozone, and OH, Geophys. Res. Lett., 32, L09813, doi:10.1029/2005g1022469, 2005.

Fountoukis, C. and Nenes, A.: ISORROPIA II: a computationally efficient thermodynamic equilibrium model for $\mathrm{K}^{+}$ $\mathrm{Ca}^{2+}-\mathrm{Mg}^{2+}-\mathrm{NH}_{4}^{+}-\mathrm{Na}^{+}-\mathrm{SO}_{4}^{2-}-\mathrm{NO}_{3}^{-}-\mathrm{Cl}^{-}-\mathrm{H}_{2} \mathrm{O}$ aerosols, Atmos. Chem. Phys., 7, 4639-4659, doi:10.5194/acp-7-4639-2007, 2007.

Fu, X., Wang, S. X., Ran, L. M., Pleim, J. E., Cooter, E., Bash, J. O., Benson, V., and Hao, J. M.: Estimating NH3 emissions from agricultural fertilizer application in China using the bidirectional CMAQ model coupled to an agro-ecosystem model, Atmos. Chem. Phys., 15, 6637-6649, doi:10.5194/acp-15-66372015, 2015.

Galloway, J. N., Dentener, F. J., Capone, D. G., Boyer, E. W., Howarth, R. W., Seitzinger, S. P., Asner, G. P., Cleveland, C. C., Green, P. A., Holland, E. A., Karl, D. M., Michaels, A. F., Porter, J. H., Townsend, A. R., and Vorosmarty, C. J.: Nitrogen cycles: past, present, and future, Biogeochemistry, 70, 153-226, 2004.

Garfinkel, C. I., Molod, A. M., Oman, L. D., and Song, I. S.: Improvement of the GEOS-5 AGCM upon updating the air-sea roughness parameterization, Geophys. Res. Lett., 38, L18702, doi:10.1029/2011GL048802, 2011.

Hains, J. C., Boersma, K., Kroon, M., Dirksen, R., Cohen, R., Perring, A., Bucsela, E., Volten, H., Swart, D., Richter, A., Wittrock, F., Schoenhardt, A., Wagner, T., Ibrahim, O., van Roozendael, M., Pinardi, G., Gleason, J., Veefkind, P., and Levelt, P.: Testing and Improving OMI DOMINO Tropospheric $\mathrm{NO}_{2}$ Using Observations from the DANDELIONS and INTEXB Validation Campaigns, J. Geophys. Res., 115, D05301, doi:10.1029/2009JD012399, 2010.

Heald, C. L., Collett Jr., J. L., Lee, T., Benedict, K. B., Schwandner, F. M., Li, Y., Clarisse, L., Hurtmans, D. R., Van Damme, M., Clerbaux, C., Coheur, P.-F., Philip, S., Martin, R. V., and Pye, H. O. T.: Atmospheric ammonia and particulate inorganic nitrogen 
over the United States, Atmos. Chem. Phys., 12, 10295-10312, doi:10.5194/acp-12-10295-2012, 2012.

Henze, D. K., Hakami, A., and Seinfeld, J. H.: Development of the adjoint of GEOS-Chem, Atmos. Chem. Phys., 7, 2413-2433, doi:10.5194/acp-7-2413-2007, 2007.

Henze, D. K., Seinfeld, J. H., and Shindell, D. T.: Inverse modeling and mapping US air quality influences of inorganic $\mathrm{PM}_{2.5}$ precursor emissions using the adjoint of GEOS-Chem, Atmos. Chem. Phys., 9, 5877-5903, doi:10.5194/acp-9-5877-2009, 2009.

Hu, C., Li, D., Chen, C., Ge, J., MullerKarger, F. E., Liu, J., Yu, F., and He, M. X.: On the recurrent Ulva prolifera blooms in the Yellow Sea and East China Sea, J. Geophys. Res.-Oceans, 115, 1978-2012, 2010.

Huang, X., Song, Y., Li, M. M., Li, J. F., Huo, Q., Cai, X. H., Zhu, T., Hu, M., and Zhang, H. S.: A high-resolution ammonia emission inventory in China, Global Biogeochem. Cy., 26, GB1030, doi:10.1029/2011GB004161, 2012.

Huijnen, V., Eskes, H. J., Poupkou, A., Elbern, H., Boersma, K. F., Foret, G., Sofiev, M., Valdebenito, A., Flemming, J., Stein, O., Gross, A., Robertson, L., D'Isidoro, M., Kioutsioukis, I., Friese, E., Amstrup, B., Bergstrom, R., Strunk, A., Vira, J., Zyryanov, D., Maurizi, A., Melas, D., Peuch, V.-H., and Zerefos, C.: Comparison of $\mathrm{OMI} \mathrm{NO}_{2}$ tropospheric columns with an ensemble of global and European regional air quality models, Atmos. Chem. Phys., 10, 3273-3296, doi:10.5194/acp-10-3273-2010, 2010.

Hyvonen, R., Persson, T., Andersson, S., Olsson, B., Agren, G. I., and Linder, S.: Impact of long-term nitrogen addition on carbon stocks in trees and soils in northern Europe, Biogeochemistry, 89, 121-137, 2008.

Jia, Y., Yu, G., He, N., Zhan, X., Fang, H., Sheng, W., Zuo, Y., Zhang, D., and Wang, Q.: Spatial and decadal variations in inorganic nitrogen wet deposition in China induced by human activity, Scientific reports, 4, 3763, doi:10.1038/srep03763, 2014.

Jiang, Z., Jones, D. B. A., Worden, J., Worden, H. M., Henze, D. K., and Wang, Y. X.: Regional data assimilation of multispectral MOPITT observations of CO over North America, Atmos. Chem. Phys., 15, 6801-6814, doi:10.5194/acp-15-68012015, 2015.

Jung, J., Furutani, H., and Uematsu, M.: Atmospheric inorganic nitrogen in marine aerosol and precipitation and its deposition to the North and South Pacific Oceans, J. Atmos. Chem., 68, 157181,2011

Kim, P. S., Jacob, D. J., Mickley, L. J., Koplitz, S. N., Marlier, M. E., DeFries, R. S., Myers, S. S., Chew, B. N., and Mao, Y. H.: Sensitivity of population smoke exposure to fire locations in Equatorial Asia, Atmos. Environ., 102, 11-17, 2015.

Kim, T. W., Lee, K., Najjar, R. G., Jeong, H. D., and Jeong, H. J.: Increasing $\mathrm{N}$ abundance in the Northwestern Pacific Ocean due to atmospheric nitrogen deposition, Science, 334, 505-509, 2011.

Kim, T. W., Lee, K., Duce, R., and Liss, P.: Impact of atmospheric nitrogen deposition on phytoplankton productivity in the South China Sea, Geophys. Res. Lett., 41, 3156-3162, 2014.

Kopacz, M., Jacob, D. J., Henze, D. K., Heald, C. L., Streets, D. G., and Zhang, Q.: Comparison of adjoint and analytical Bayesian inversion methods for constraining Asian sources of carbon monoxide using satellite (MOPITT) measurements of CO columns, J. Geophys. Res.-Atmos., 114, D04305, doi:10.1029/2007JD009264, 2009.
Koracin, D. and Berkowicz, R.: Nocturnal boundary-layer height: Observations by acoustic sounders and predictions in terms of surface-layer parameters, Bound.-Lay. Meteorol., 43, 65-83, 1988.

Kurokawa, J., Ohara, T., Morikawa, T., Hanayama, S., JanssensMaenhout, G., Fukui, T., Kawashima, K., and Akimoto, H.: Emissions of air pollutants and greenhouse gases over Asian regions during 2000-2008: Regional Emission inventory in ASia (REAS) version 2, Atmos. Chem. Phys., 13, 11019-11058, doi:10.5194/acp-13-11019-2013, 2013.

Lamsal, L. N., Martin, R. V., van Donkelaar, A., Celarier, E. A., Bucsela, E. J., Boersma, K. F., Dirksen, R., Luo, C., and Wang, Y.: Indirect validation of tropospheric nitrogen dioxide retrieved from the OMI satellite instrument: Insight into the seasonal variation of nitrogen oxides at northern midlatitudes, J. Geophys. Res., 115, D05302, doi:10.1029/2009jd013351, 2010.

Levelt, P. F., Hilsenrath, E., Leppelmeier, G. W., van den Oord, G. H. J., Bhartia, P. K., Tamminen, J., de Haan, J. F., and Veefkind, J. P.: Science objectives of the Ozone monitoring instrument, IEEE T. Geosci. Remote, 44, 1199-1208, 2006.

Liang, Q., Jaeglé, L., Jaffe, D. A., Weiss-Penzias, P., Heckman, A., and Snow, J. A.: Long-range transport of Asian pollution to the northeast Pacific: seasonal variations and transport pathways of carbon monoxide, J. Geophys. Res., 109, D23S07, doi:10.1029/2003JD004402, 2004.

Liao, J.: Fertilizer application and analysis, Shanghai science and Technology Press, Shanghai, 1993.

Lin, J.-T., Martin, R. V., Boersma, K. F., Sneep, M., Stammes, P., Spurr, R., Wang, P., Van Roozendael, M., Clémer, K., and Irie, H.: Retrieving tropospheric nitrogen dioxide from the Ozone Monitoring Instrument: effects of aerosols, surface reflectance anisotropy, and vertical profile of nitrogen dioxide, Atmos. Chem. Phys., 14, 1441-1461, doi:10.5194/acp-14-1441-2014, 2014.

Liu, H. Y., Jacob, D. J., Bey, I., and Yantosca, R. M.: Constraints from $\mathrm{Pb}-210$ and $\mathrm{Be}-7$ on wet deposition and transport in a global three-dimensional chemical tracer model driven by assimilated meteorological fields, J. Geophys. Res., 106, 12109 12128, 2001.

Liu, H. Y., Jacob, D. J., Bey, I., Yantosca, R. M., Duncan, B. N., and Sachse, G. W.: Transport pathways for Asian pollution outflow over the Pacific: interannual and seasonal variations, J. Geophys. Res.-Atmos., 108, 8786, doi:10.1029/2002JD003102, 2003.

Liu, X. J., Zhang, Y., Han, W. X., Tang, A. H., Shen, J. L., Cui, Z. L., Vitousek, P., Erisman, J. W., Goulding, K., Christie, P., Fangmeier, A., and Zhang, F. S.: Enhanced nitrogen deposition over China, Nature, 494, 459-462, 2013.

Luo, X. S., Tang, A. H., Shi, K., Wu, L. H., Li, W. Q., Shi, W. Q., Shi, X. K., Erisman, J. W., Zhang, F. S., and Liu, X. J.: Chinese coastal seas are facing heavy atmospheric nitrogen deposition, Environ. Res. Lett., 9, 095007, doi:10.1088/17489326/9/9/095007, 2014.

Lv, C. Q. and Tian, H. Q.: Spatial and temporal patterns of nitrogen deposition in China: synthesis of observational data, J. Geophys. Res.-Atmos., 112, D22S05, doi:10.1029/2006JD007990, 2007.

Ma, J. Z., Beirle, S., Jin, J. L., Shaiganfar, R., Yan, P., and Wagner, T.: Tropospheric $\mathrm{NO}_{2}$ vertical column densities over Beijing: results of the first three years of ground-based MAX-DOAS mea- 
surements (2008-2011) and satellite validation, Atmos. Chem. Phys., 13, 1547-1567, doi:10.5194/acp-13-1547-2013, 2013.

Mao, J., Jacob, D. J., Evans, M. J., Olson, J. R., Ren, X., Brune, W. H., Clair, J. M. St., Crounse, J. D., Spencer, K. M., Beaver, M. R., Wennberg, P. O., Cubison, M. J., Jimenez, J. L., Fried, A., Weibring, P., Walega, J. G., Hall, S. R., Weinheimer, A. J., Cohen, R. C., Chen, G., Crawford, J. H., McNaughton, C., Clarke, A. D., Jaeglé, L., Fisher, J. A., Yantosca, R. M., Le Sager, P., and Carouge, C.: Chemistry of hydrogen oxide radicals $\left(\mathrm{HO}_{x}\right)$ in the Arctic troposphere in spring, Atmos. Chem. Phys., 10, 5823-5838, doi:10.5194/acp-10-58232010, 2010.

Mao, Y. H., Li, Q. B., Henze, D. K., Jiang, Z., Jones, D. B. A., Kopacz, M., He, C., Qi, L., Gao, M., Hao, W.-M., and Liou, K.N.: Estimates of black carbon emissions in the western United States using the GEOS-Chem adjoint model, Atmos. Chem. Phys., 15, 7685-7702, doi:10.5194/acp-15-7685-2015, 2015.

Mari, C., Jacob, D. J., and Bechtold, P.: Transport and scavenging of soluble gases in a deep convective cloud, J. Geophys. Res.Atmos., 105, 22255-22267, 2000.

Martin, R. V., Jacob, D. J., Chance, K., Kurosu, T. P., Palmer, P. I., and Evans, M. J.: Global inventory of nitrogen oxide emissions constrained by space-based observations of $\mathrm{NO}_{2}$ columns, J. Geophys. Res., 108, 4537, doi:10.1029/2003JD003453, 2003.

Martin, R. V., Sauvage, B., Folkins, I., Sioris, C. E., Boone, C., Bernath, P., and Ziemke, J.: Spacebased constraints on the production of nitric oxide by lightning, J. Geophys. Res.-Atmos, 112, D09309, 1984-2012, 2007.

Monfreda, C., Ramankutty, N., and Foley, J. A.: Farming the planet: 2. Geographic distribution of crop areas, yields, physiological types, and net primary production in the year 2000, Global Biogeochem. Cy., 22, GB1022, doi:10.1029/2007GB002947, 2008.

Murray, L. T., Jacob, D. J., Logan, J. A., Hudman, R. C., and Koshak, W. J.: Optimized regional and interannual variability of lightning in a global chemical transport model constrained by LIS/OTD satellite data, J. Geophys. Res.-Atmos., 117, D20307, doi:10.1029/2012JD017934, 2012.

O’Byrne, G., Martin, R. V., van Donkelaar, A., Joiner, J., and Celarier, E. A.: Surface reflectivity from the Ozone Monitoring Instrument using the Moderate Resolution Imaging Spectroradiometer to eliminate clouds: effects of snow on ultraviolet and visible trace gas retrievals, J. Geophys. Res., 115, D17305, doi:10.1029/2009JD013079, 2010.

Olivier, J. G. J. and Berdowski, J. J. M.: Global emissions sources and sinks, in: The Climate System, edited by: Berdowski, J., Guicherit, R., and Heij, B. J., A. A. Balkema Publishers/Swets and Zeitlinger Publishers, Lisse, the Netherlands, 33-78, ISBN: 9058092550, 2001.

Pan, Y. P., Wang, Y. S., Tang, G. Q., and Wu, D.: Wet and dry deposition of atmospheric nitrogen at ten sites in Northern China, Atmos. Chem. Phys., 12, 6515-6535, doi:10.5194/acp-12-65152012, 2012.

Park, R. J., Jacob, D. J., Field, B. D., Yantosca, R. M., and Chin, M.: Natural and transboundary pollution influences on sulfate-nitrate-ammonium aerosols in the United States: implications for policy, J. Geophys. Res.-Atmos., 109, D15204, doi:10.1029/2003JD004473, 2004.

Paulot, F., Jacob, D. J., and Henze, D. K.: Sources and processes contributing to nitrogen deposition: an adjoint model analysis ap- plied to biodiversity hotspots worldwide, Environ. Sci. Technol., 47, 3226-3233, 2013.

Paulot, F., Jacob, D. J., Pinder, R. W., Bash, J. O., Travis, K., and Henze, D. K.: Ammonia emissions in the United States, European Union, and China derived by high-resolution inversion of ammonium wet deposition data: interpretation with a new agricultural emissions inventory (MASAGE_NH3), J. Geophys. Res.-Atmos., 119, 4343-4364, 2014.

Paulot, F., Jacob, D. J., Johnson, M. T., Bell, T. G., Baker, A. R., Keene, W. C., Lima, I. D., Doney, S. C., and Stock, C. A.: Global oceanic emission of ammonia: Constraints from seawater and atmospheric observations, Global Biogeochem. Cy., doi:10.1002/2015GB005106, online first, 2015.

Pickering, K. E., Wang, Y. S., Tao, W. K., Price, C., and Muller, J. F.: Vertical distributions of lightning $\mathrm{NO}_{x}$ for use in regional and global chemical transport models, J. Geophys. Res.-Atmos., 103, 31203-31216, 1998.

Pinder, R. W., Adams, P. J., Pandis, S. N., and Gilliland, A. B.: Temporally resolved ammonia emission inventories: current estimates, evaluation tools, and measurement needs, J. Geophys. Res.-Atmos., 111, 1984-2012, 2006.

Price, C. and Rind, D.: A simple lightning parameterization for calculating global lightning distributions, J. Geophys. Res.-Atmos., 97, 9919-9933, 1992.

Pregitzer, K. S., Burton, A. J., Zak, D. R., and Talhelm, A. F.: Simulated chronic nitrogen deposition increases carbon storage in Northern Temperate forests, Glob. Change Biol., 14, 142-153, 2008.

Rodgers, C. D.: Inverse Methods for Atmospheric Sounding - Theory and Practise, edited by: Taylor, F. W., World Scientific, Singapore, 2000.

Sacks, W. J., Deryng, D., Foley, J. A., and Ramankutty, N.: Crop planting dates: an analysis of global patterns, Global Ecol. Biogeogr., 19, 607-620, 2010.

Sanderson, M. G., Dentener, F. J., Fiore, A. M., Cuvelier, C., Keating, T. J., Zuber, A., Atherton, C. S., Bergmann, D. J., Diehl, T., Doherty, R. M., Duncan, B. N., Hess, P., Horowitz, L. W., Jacob, D. J., Jonson, J. E., Kaminski, J. W., Lupu, A., MacKenzie, I. A., Mancini, E., Marmer, E., Park, R., Pitari, G., Prather, M. J., Pringle, K. J., Schroeder, S., Schultz, M. G., Shindell, D. T., Szopa, S., Wild, O., and Wind, P.: A multimodel study of the hemispheric transport and deposition of oxidised nitrogen, Geophys. Res. Lett., 35, L17815, doi:10.1029/2008GL035389, 2008.

Sauvage, B., Martin, R. V., van Donkelaar, A., Liu, X., Chance, K., Jaeglé, L., Palmer, P. I., Wu, S., and Fu, T.-M.: Remote sensed and in situ constraints on processes affecting tropical tropospheric ozone, Atmos. Chem. Phys., 7, 815-838, doi:10.5194/acp-7-815-2007, 2007.

Seitzinger, S., Harrison, J. A., Bohlke, J. K., Bouwman, A. F., Lowrance, R., Peterson, B., Tobias, C., and Van Drecht, G.: Denitrification across landscapes and waterscapes: a synthesis, Ecol. Appl., 16, 2064-2090, 2006.

Shephard, M. W., Cady-Pereira, K. E., Luo, M., Henze, D. K., Pinder, R. W., Walker, J. T., Rinsland, C. P., Bash, J. O., Zhu, L., Payne, V. H., and Clarisse, L.: TES ammonia retrieval strategy and global observations of the spatial and seasonal variability of ammonia, Atmos. Chem. Phys., 11, 10743-10763, doi:10.5194/acp-11-10743-2011, 2011. 
Skjøth, C. A., Geels, C., Berge, H., Gyldenkærne, S., Fagerli, H., Ellermann, T., Frohn, L. M., Christensen, J., Hansen, K. M., Hansen, K., and Hertel, O.: Spatial and temporal variations in ammonia emissions - a freely accessible model code for Europe, Atmos. Chem. Phys., 11, 5221-5236, doi:10.5194/acp-11-52212011, 2011.

Stevens, C. J., Dise, N. B., Mountford, J. O., and Gowing, D. J.: Impact of nitrogen deposition on the species richness of grasslands, Science, 303, 1876-1879, 2004.

Streets, D. G., Bond, T. C., Carmichael, G. R., Fernandes, S. D., Fu, Q., He, D., Klimont, Z., Nelson, S. M., Tsai, N. Y., Wang, M. Q., Woo, J. H., and Yarber, K. F.: An inventory of gaseous and primary aerosol emissions in Asia in the year 2000, J. Geophys. Res.-Atmos., 108, 8809, doi:10.1029/2002JD003093, 2003.

Sutton, M. A., Burkhardt, J. K., Guerin, D., Nemitz, E., and Fowler, D.: Development of resistance models to describe measurements of bi-directional ammonia surface-atmosphere exchange, Atmos. Environ., 32, 473-480, 1998.

van der Werf, G. R., Randerson, J. T., Giglio, L., Collatz, G. J., Kasibhatla, P. S., and Arellano Jr., A. F.: Interannual variability in global biomass burning emissions from 1997 to 2004, Atmos. Chem. Phys., 6, 3423-3441, doi:10.5194/acp-6-3423-2006, 2006.

Vestreng, V. and Klein, H.: Emission data reported to UNECE/EMEP: quality assurance and trend analysis and Presentation of WebDab, MSC-W Status Report 2002, Norwegian Meteorological Institute, Oslo, Norway, 2002.

Vinken, G. C. M., Boersma, K. F., Jacob, D. J., and Meijer, E. W.: Accounting for non-linear chemistry of ship plumes in the GEOS-Chem global chemistry transport model, Atmos. Chem. Phys., 11, 11707-11722, doi:10.5194/acp-11-11707-2011, 2011.

Wang, J., Hoffmann, A. A., Park, R. J., Jacob, D. J., and Martin, S. T.: Global distribution of solid and aqueous sulfate aerosols: effect of the hysteresis of particle phase transitions, J. Geophys. Res., 113, D11206, doi:10.1029/2007JD009367, 2008.

Wang, Y. H., Jacob, D. J., and Logan, J. A.: Global simulation of tropospheric $\mathrm{O}_{3}-\mathrm{NO}_{x}$-hydrocarbon chemistry, 3. Origins of tropospheric ozone and effects of nonmethance hydrocarbons, J. Geophys. Res., 103, 10757-10767, 1998.

Wang, Y., Zhang, Q. Q., He, K., Zhang, Q., and Chai, L.: Sulfatenitrate-ammonium aerosols over China: response to 2000-2015 emission changes of sulfur dioxide, nitrogen oxides, and ammonia, Atmos. Chem. Phys., 13, 2635-2652, doi:10.5194/acp-132635-2013, 2013.

Wesely, M. L.: Parameterization of surface resistances to gaseous dry deposition in regional-scale numerical-models, Atmos. Environ., 23, 1293-1304, 1989.

Xie, P. P. and Arkin, P. A.: Global precipitation: a 17 year monthly analysis based on gauge observations, satellite estimates, and numerical model outputs, B. Am. Meteorol. Soc., 78, 2539-2558, 1997.

Yienger, J. J. and Levy, H.: Empirical-model of global soil-biogenic $\mathrm{NO}_{x}$ emissions, J. Geophys. Res.-Atmos., 100, 11447-11464, 1995.

Zhang, B., Owen, R. C., Perlinger, J. A., Kumar, A., Wu, S., Val Martin, M., Kramer, L., Helmig, D., and Honrath, R. E.: A semi-Lagrangian view of ozone production tendency in North American outflow in the summers of 2009 and 2010, Atmos.
Chem. Phys., 14, 2267-2287, doi:10.5194/acp-14-2267-2014, 2014.

Zhang, L., Jacob, D. J., Bowman, K. W., Logan, J. A., Turquety, S., Hudman, R. C., Li, Q. B., Beer, R., Worden, H. M., Worden, J. R., Rinsland, C. P., Kulawik, S. S., Lampel, M. C., Shephard, M. W., Fisher, B. M., Eldering, A., and Avery, M. A.: Ozone-CO correlations determined by the TES satellite instrument in continental outflow regions, Geophys. Res. Lett., 33, L18804, doi:10.1029/2006GL026399, 2006.

Zhang, L., Jacob, D. J., Kopacz, M., Henze, D. K., Singh, K., and Jaffe, D. A.: Intercontinental source attribution of ozone pollution at western US sites using an adjoint method, Geophys. Res. Lett., 36, L11810, doi:10.1029/2009GL037950, 2009.

Zhang, L., Liao, H., and Li, J.: Impacts of Asian summer monsoon on seasonal and interannual variations of aerosols over eastern China, J. Geophys. Res., 115, D00K05, doi:10.1029/2009JD012299, 2010.

Zhang, L., Jacob, D. J., Knipping, E. M., Kumar, N., Munger, J. W., Carouge, C. C., van Donkelaar, A., Wang, Y. X., and Chen, D.: Nitrogen deposition to the United States: distribution, sources, and processes, Atmos. Chem. Phys., 12, 4539-4554, doi:10.5194/acp-12-4539-2012, 2012.

Zhang, L., Jacob, D. J., Yue, X., Downey, N. V., Wood, D. A., and Blewitt, D.: Sources contributing to background surface ozone in the US Intermountain West, Atmos. Chem. Phys., 14, 52955309, doi:10.5194/acp-14-5295-2014, 2014.

Zhang, L., Liu, L., Zhao, Y., Gong, S., Zhang, X., Henze, D. K., Capps, S. L., Fu, T.-M., Zhang, Q., and Wang, Y.: Source attribution of particulate matter pollution over North China with the adjoint method, Environ. Res. Lett., 10, 084011, doi:10.1088/17489326/10/8/084011, 2015.

Zhang, Q., Streets, D. G., Carmichael, G. R., He, K. B., Huo, H., Kannari, A., Klimont, Z., Park, I. S., Reddy, S., Fu, J. S., Chen, D., Duan, L., Lei, Y., Wang, L. T., and Yao, Z. L.: Asian emissions in 2006 for the NASA INTEX-B mission, Atmos. Chem. Phys., 9, 5131-5153, doi:10.5194/acp-9-5131-2009, 2009.

Zhang, Y., Yu, Q., Ma, W. C., and Chen, L. M.: Atmospheric deposition of inorganic nitrogen to the eastern China seas and its implications to marine biogeochemistry, J. Geophys. Res.-Atmos., 115, D00K10, doi:10.1029/2009JD012814, 2010.

Zhu, J., He, N., Wang, Q., Yuan, G., Wen, D., Yu, G., and Jia, Y.: The composition, spatial patterns, and influencing factors of atmospheric wet nitrogen deposition in Chinese terrestrial ecosystems, Sci. Total Environ., 511, 777-785, 2015.

Zhu, L., Henze, D. K., Cady-Pereira, K. E., Shephard, M. W., Luo, M., Pinder, R. W., Bash, J. O., and Jeong, G. R.: Constraining U.S. ammonia emissions using TES remote sensing observations and the GEOS-Chem adjoint model, J. Geophys. Res.-Atmos., 118, 3355-3368, 2013.

Zhu, L., Henze, D., Bash, J., Jeong, G.-R., Cady-Pereira, K., Shephard, M., Luo, M., Paulot, F., and Capps, S.: Global evaluation of ammonia bi-directional exchange, Atmos. Chem. Phys. Discuss., 15, 4823-4877, doi:10.5194/acpd-15-4823-2015, 2015. 